\title{
The mating pair formation system of conjugative plasmids - A versatile secretion machinery for transfer of proteins and DNA
}

\author{
Gunnar Schröder ${ }^{\mathrm{a}, *}$, Erich Lanka ${ }^{\mathrm{b}}$ \\ a Division of Molecular Microbiology, Biozentrum, University of Basel, Klingelbergstrasse 50/70, CH-4056 Basel, Switzerland \\ ${ }^{\mathrm{b}}$ Max-Planck-Institut für Molekulare Genetik, Ihnestrasse 73, Dahlem, D-14195 Berlin, Germany \\ Received 17 January 2005, revised 21 February 2005 \\ Available online 27 April 2005 \\ Communicated by D.K. Chattoraj
}

\begin{abstract}
The mating pair formation (Mpf) system functions as a secretion machinery for intercellular DNA transfer during bacterial conjugation. The components of the Mpf system, comprising a minimal set of 10 conserved proteins, form a membrane-spanning protein complex and a surface-exposed sex pilus, which both serve to establish intimate physical contacts with a recipient bacterium. To function as a DNA secretion apparatus the Mpf complex additionally requires the coupling protein $(\mathrm{CP})$. The $\mathrm{CP}$ interacts with the DNA substrate and couples it to the secretion pore formed by the Mpf system. Mpf/CP conjugation systems belong to the family of type IV secretion systems (T4SS), which also includes DNA-uptake and -release systems, as well as effector protein translocation systems of bacterial pathogens such as Agrobacterium tumefaciens (VirB/VirD4) and Helicobacter pylori (Cag). The increased efforts to unravel the molecular mechanisms of type IV secretion have largely advanced our current understanding of the Mpf/CP system of bacterial conjugation systems. It has become apparent that proteins coupled to DNA rather than DNA itself are the actively transported substrates during bacterial conjugation. We here present a unified and updated view of the functioning and the molecular architecture of the Mpf/CP machinery.
\end{abstract}

(c) 2005 Elsevier Inc. All rights reserved.

Keywords: Mating pair formation; Mpf system; Bacterial conjugation; Type IV secretion; DNA transfer; Protein secretion

\footnotetext{
* Corresponding author. Fax: +410612672118.

E-mail addresses: gunnar.schroeder@unibas.ch (G. Schröder), lanka@molgen.mpg.de (E. Lanka).
}

\section{Introduction}

Bacterial conjugation, often referred to as 'bacterial sex' is one of the major routes of horizontal gene transfer and accounts for the rapid spread of antibiotic resistance genes among pathogenic 
bacteria (Waters, 1999). Mechanistically, conjugative plasmids first undergo processing into a transfer-competent form, and are then transferred into a recipient bacterium where they subsequently replicate. Conjugative plasmids can spread autonomously since they are equipped with the entire set of genes that are required for plasmid transfer. Many of the conjugative plasmids are supplied with broad host range properties among Gram-negative species and a small number of these plasmids can also transfer between and replicate in both Gramnegative and Gram-positive bacteria (Charpentier et al., 1999; Gormley and Davis, 1991; Kurenbach et al., 2003; Trieu-Cuot et al., 1987). Intriguingly, conjugative DNA transfer between bacteria and eukaryotic cells has also been reported (Heinemann and Sprague, 1989; Waters, 2001), demonstrating that bacterial conjugation contributes to genetic exchange going even beyond the bacterial kingdom.

The genetic framework of conjugation systems has been grouped into two functional subsets belonging to the DNA transfer and replication (Dtr) and the mating pair formation (Mpf) systems (Willetts, 1981). The Dtr system is responsible for plasmid replication and processing of the conjugative plasmid into a transfer-competent intermediate (a protein-DNA conjugate). The Mpf system is essential for production of exocellular pili and formation of a trans-envelope channel structure presumably serving as a conduit for protein and DNA substrates. A third function, mediating between Dtr and Mpf, is carried out by the coupling protein (CP, VirD4). The $\mathrm{CP}$ first delivers the protein-DNA substrate generated by the Dtr to the entry of the Mpf channel and then probably participates in the active secretion of the substrate. Plasmids that lack a Mpf system but encode their own Dtr and, optionally, their own CP, are frequently found. Such plasmids, called mobilizable (Mob) plasmids, can be transferred from one bacterium to another in case a Mpf system able to interact with the Dtr system of the Mob plasmid is present in the same donor bacterium (encoded either on a second plasmid or on the chromosome). Studies carried out with Mob plasmids have therefore largely contributed in identifying the genetic determinants of the Mpf and Dtr systems and, specifically, the role of the $\mathrm{CP}$.
Long after the first discovery of bacterial conjugation, which dates back to 1946 (Lederberg and Tatum, 1946), a series of pathogenicity-associated secretion systems delivering toxic protein or DNA substrates into eukaryotic host cells were discovered to be sequence-related to bacterial conjugation systems (Lessl and Lanka, 1994; Lessl et al., 1992). These secretion systems are grouped into the family of type IV secretion systems (T4SS), as originally proposed by Salmond (1994) (Table 1). The family of T4SS includes the VirB/VirD4 system encoded by the Agrobacterium tumefaciens Ti plasmid, which is responsible for the formation of tumors in infected plant tissues. The VirB/VirD4 system secretes an oncogenic DNA fragment (TDNA), which, similar to conjugation systems, is processed into a transfer-competent protein-DNA conjugate before transfer. Proteins that are secreted along with the T-DNA enable import of the T-DNA into the nucleus and integration of the T-DNA into the plant chromosome. Other T4SS target effector proteins or toxins into infected host cells. These include the T4SS of Bordetella pertussis (Pt), Helicobacter pylori (Cag), and Bartonella henselae (VirB/VirD4), responsible for whooping cough, gastric diseases, and cat scratch disease, respectively (Cascales and Christie, 2003; Schröder et al., 2005).

Numerous studies on Mpf/CP systems of bacterial conjugation systems and of other T4SS have aimed to assign specific functions to individual Mpf components and their contribution to the secretion process. Since these components are networked within a tight complex that is integrated into the bacterial membranes, this has often been a difficult objective. However, based on a conserved set of proteins that are found in most T4SS (Fig. 1), we are now able to present a unified view of a 'model' Mpf system, assigning functions to the 'key players' VirB1-VirB11 and the CP (VirD4).

\section{The foreplay of bacterial sex: mating pair formation}

How do bacteria have sex? The first requirements are: find a partner cell, get close to it, and 
Table 1

T4SS of pathogenic bacteria

\begin{tabular}{|c|c|c|c|c|c|}
\hline Host bacterium (plasmid) & T4SS & Known substrate(s) & Target cells & T4SS-associated disease & References (most recent) \\
\hline $\begin{array}{l}\text { Agrobacterium } \\
\quad \text { tumefaciens }(\mathrm{pTi})\end{array}$ & VirB/VirD4 & $\begin{array}{l}\text { T-DNA, VirD2, VirD5, } \\
\text { VirE2, VirE3, VirF }\end{array}$ & Plant cells & Crown gall tumor & $\begin{array}{l}\text { Christie (2004) } \\
\text { Vergunst et al. (2005) }\end{array}$ \\
\hline Bartonella henselae & VirB/VirD4 & BepA-BepG & $\begin{array}{l}\text { Erythrocytes, } \\
\text { vascular epithelial } \\
\text { cells of mammals }\end{array}$ & $\begin{array}{l}\text { Intraerythrocytic } \\
\text { bacteremia, } \\
\text { cat scratch disease }\end{array}$ & $\begin{array}{l}\text { Dehio (2004) and } \\
\text { Schulein et al. (2005) }\end{array}$ \\
\hline Bordetella pertussis & Ptl & Pertussis toxin & $\begin{array}{l}\text { Human ciliated } \\
\text { respiratory-epithelial cells }\end{array}$ & Whooping cough & Weiss et al. (1993) \\
\hline Brucella suis & VirB & $?$ & Macrophages & Brucellosis & $\begin{array}{l}\text { Boschiroli et al. (2002) and } \\
\text { Celli and Gorvel (2004) }\end{array}$ \\
\hline Campylobacter jejuni (pVir) & VirB & $?$ & Intestinal epithelial cells & Diarrheal disease & Bacon et al. $(2000,2002)$ \\
\hline Coxiella burnetii & $\operatorname{Dot} / \mathrm{Icm}^{\mathrm{a}}$ & $?$ & Mononuclear phagocytes & Q fever & $\begin{array}{l}\text { Segal et al. (2005) and } \\
\text { Zamboni et al. (2003) }\end{array}$ \\
\hline Helicobacter pylori & $\mathrm{Cag}$ & CagA & Gastric epithelial cells & Gastric diseases & $\begin{array}{l}\text { Backert et al. (2002) and } \\
\text { Stein et al. (2000) }\end{array}$ \\
\hline Legionella pneumophila & Dot/Icm & $\begin{array}{l}\text { LidA, RalF, LepA, Lep B, } \\
\text { SidA-SidH, SdbA-SdbD, } \\
\text { SdcA-SdcB, SdeA-SdeE, SdhA-SdhC }\end{array}$ & Macrophages, protozoa & $\begin{array}{l}\text { Pneumonia } \\
\text { (Legionnaires' disease) }\end{array}$ & $\begin{array}{l}\text { Chen et al. (2004), } \\
\text { Conover et al. (2003), } \\
\text { Luo and Isberg (2004), and } \\
\text { Sexton and Vogel (2002) }\end{array}$ \\
\hline
\end{tabular}

${ }^{\mathrm{a}}$ An implication of this T4SS in pathogenicity has not yet been demonstrated. 


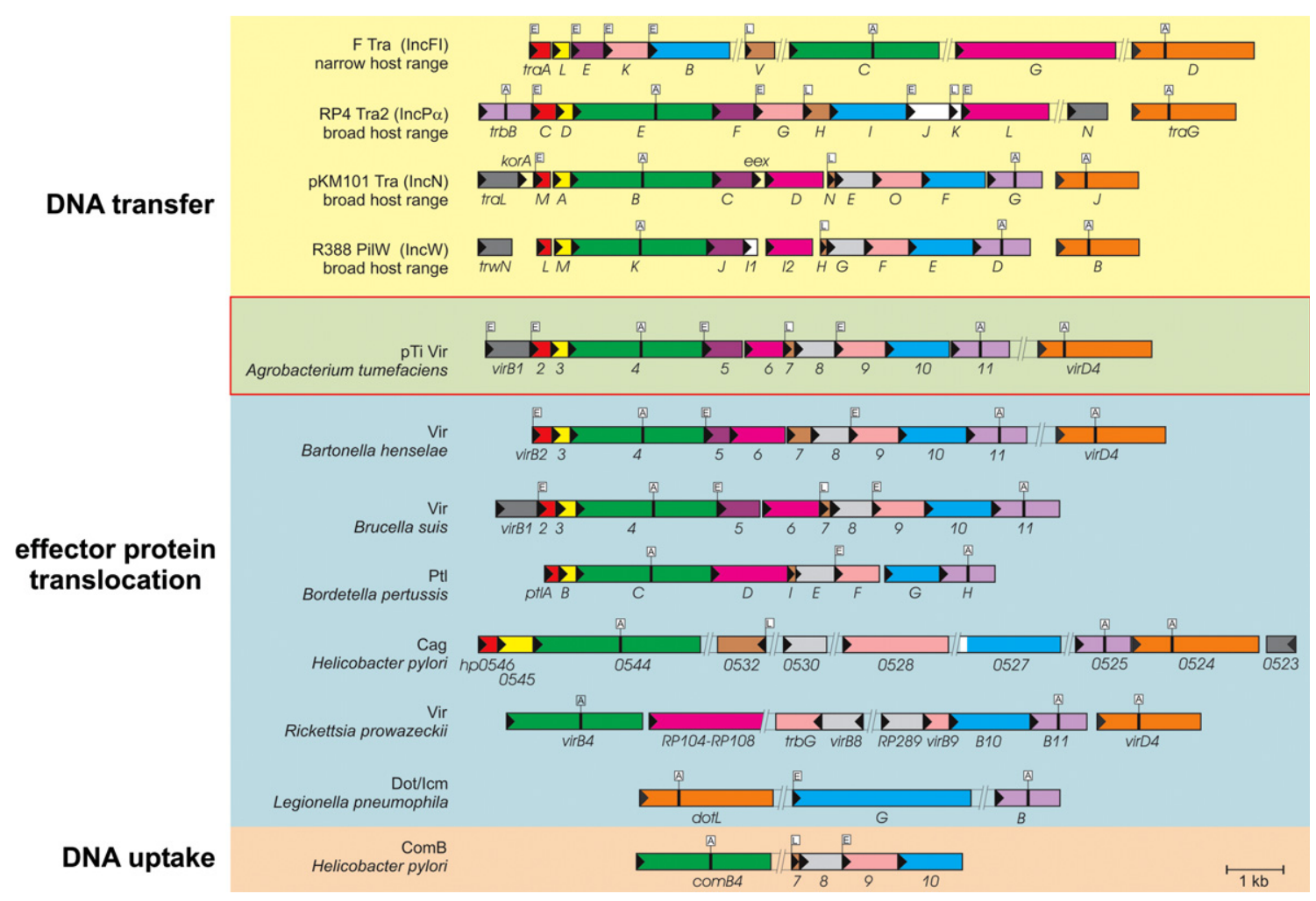

Fig. 1. Conserved genes in Mpf/CP and related type IV secretion systems. The set of VirB-like genes, with reference to the paradigm of the A. tumefaciens VirB/VirD4 system, is conserved in a large number of secretion systems transporting DNA (yellow background), effector proteins (blue background), or both (green backround). A subset of these components is functional for DNA uptake (orange background). Genes are represented in correct relative size and gene order, with arrowheads indicating the start sites. Homologous genes are shown in identical colours. Predicted peptide motifs are indicated by boxed letters: A, Walker A nucleotide-binding motif; E, export signal peptide; L, lipoprotein signal peptide.

sense whether it is "willing" to conjugate. The sex pilus that is produced by the Mpf system is thought to exactly serve these purposes. It is an elongated, tubular, appendage of the cell that mediates initial contact between donor and recipient cells, and brings the cell surfaces into close proximity. Sex pili have been detected in most bacterial conjugation systems (Frost, 1993) and also in the A. tumefaciens VirB/VirD4 system, where this structure is called the T-pilus (Fullner et al., 1996; Lai and Kado, 2000). In conjugation systems, two major types of pili are distinguished: F-like pili (produced by IncF, $-\mathrm{H},-\mathrm{T}$, and $-\mathrm{J}$ systems) and P-like pili (produced by IncP, -N, -W, and -I systems) (Lawley et al., 2003). F-like pili are long and flexible, measuring 2-20 $\mu \mathrm{m}$ in length and $8 \mathrm{~nm}$ in width with a central lumen of $2 \mathrm{~nm}$. By contrast, P-pili are shorter $(0.2-1 \mu \mathrm{m})$ and rigid and therefore easily break off from the pilusproducing cells. The number of sex pili produced per bacterium is usually rather low; depending of the host strain, 1-4 pili are detected in F plasmid carrying bacteria [(Novotny and Lavin, 1971) and references cited therein] and the average number of pili produced by other conjugation systems lies in a similar range. Pili are produced both on the lateral sides and on the poles of a bacterium, although in case of the A. tumefaciens T-pili they are more abundantly found at cell poles (Lai et al., 2000). Likewise, the Mpf transport apparatus of A. tumefaciens (VirB/VirD4) localizes to the bacterial poles (Atmakuri et al., 2003; Judd et al., 2005; Kumar and Das, 2002). This difference of the $A$. tumefaciens VirB/VirD4 system versus bacterial conjugation systems is also reflected in the observed 
donor-recipient interactions: whereas bacterial mating pairs have been observed to form in all possible relative positions (side-to-side, pole-to-pole, side-to-pole, and pole-to-side of donor and recipient, respectively) (Lawley et al., 2002), the attachment of A. tumefaciens to plant cells seems to occur mainly in a polar manner (Matthysse, 1987).

Sex pili are composed of a small subunit, the pilin (VirB2), which assembles into a filamentous pilus structure at the cell surface (Eisenbrandt et al., 1999; Lai and Kado, 1998). Two additional proteins, VirB5 and VirB7, localize to the pilus (Sagulenko et al., 2001b; Schmidt-Eisenlohr et al., 1999a). Little is known about specific receptors allowing the pilus to attach to a recipient cell. Outer-membrane protein A (OmpA) and the lipopolysaccharide (LPS) of Escherichia coli are required in recipients for efficient mating pair formation during $\mathrm{F}$ plasmid-mediated conjugation in liquid cultures; however, a direct interaction of OmpA or the LPS with a pilus component has not been demonstrated (Achtman et al., 1978b; Anthony et al., 1994; Skurray et al., 1974). Four receptors have recently been identified in Arabidopsis thaliana plant cells infected by $A$. tumefaciens. The pilus subunit, VirB2, was seen to specifically interact with a membrane-associated GTPase, AtRAB8, and three $A$. thaliana proteins of unknown function (Hwang and Gelvin, 2004). It remains uncertain whether bacterial conjugation systems use a common strategy for pilus attachment to outer-membrane receptors of a recipient cell. The presence of an adhesin-like component associated to the pilus, VirB5, is suggested by recent reports (see below). A search for VirB5interacting receptors may in future provide evidence for its postulated role as an adhesin.

Once an interaction between the pilus and a recipient cell has occurred, the two partner cells draw near. It has been speculated for systems producing F-like pili that the reapproachement of partner cells may function through retraction of the pilus, which may be achieved by depolymerization of pilus subunits (Achtman et al., 1978a; Curtiss, 1969). The identification of spiral-like variants of the normally elongated $\mathrm{T}$-pilus indicates that $\mathrm{T}$ pili may retract through winding up (Lai and Kado, 2000). The pilus may thus function as a grapple, by first capturing and then pulling up the recipient cell. For systems producing rigid pili (P pili) such retraction mechanisms can, however, be excluded. When the two partner cells are close together they form a mating pair. Characteristically, mating pairs contain zones of intimate cellcell contacts in which the outer membranes of donor and recipient are not anymore separated by exocellular material. As seen in electron microscopic images, the outer membranes fuse with a layer of electron dense material over large sections of the cell, called "conjugative junctions" (Dürrenberger et al., 1991; Samuels et al., 2000). It is worth noticing that these junctions are not composed of pilin (Samuels et al., 2000).

Conjugation with recipient bacteria that already carry the plasmid to be transferred is specifically inhibited by the entry exclusion (Eex) system encoded on conjugative plasmids. Each plasmid has its own Eex system, but some plasmids encode related Eex systems and therefore inhibit the conjugative uptake of plasmids belonging to the same Eex group. How does entry exclusion work? Two different mechanisms are known. The first one interferes with the initial attachment of a donor bacterium to a potential recipient. An outer-membrane Eex protein such as TraT of the F plasmid prevents the bacterium from becoming a recipient for conjugation; this functions through inhibiting the binding of pili of donor bacteria to the cell surface of the recipient (Achtman et al., 1977; Riede and Eschbach, 1986). The second mechanism mediating entry exclusion acts at a later stage, when mating pairs have already formed. At this stage, the entry of DNA is inhibited by the presence of a protein localizing at the inner membrane of the recipient cell. Examples are TraS of the F plasmid, which acts conjointly with TraT to mediate entry exclusion (Achtman et al., 1977), or TrbK of plasmid RP4, which is the only Eex component of RP4 (Haase et al., 1996).

\section{The Mpf/CP secretion machinery: 12 components packed into an envelope}

VirB1-VirB11 and VirD4 encoded on the A. tumefaciens Ti plasmid constitute a functional 
protein and DNA secretion machinery. These proteins, called VirB-like components, are wellconserved among the majority of T4SS, including the conjugation systems of the plasmids belonging to incompatibility groups IncN, IncW, IncX, and IncP and the pXF51/pSB102/pIPO2-like plasmids (Fig. 1). Type IVb secretion systems (T4bSS) like the Dot/Icm system of Legionella pneumophila, as well as some of the bacterial conjugation systems (plasmids of incompatibility groups $\mathrm{IncF}$, IncH, and IncI), are more divergent from VirB-like systems. These systems lack some of the conserved VirB-like components and, in turn, encode $\mathrm{Mpf}$ proteins that do not have a counterpart in VirBlike systems. However, type $\mathrm{IVb}$ and $\mathrm{IncF},-\mathrm{H}$, and -I systems possibly encode functional homologues of the entire set of conserved VirB-like components. In the following, we present an overview on the function of the 12 VirB-like components, which are the most conserved and best-studied components of $\mathrm{Mpf} / \mathrm{CP}$ systems. Each of these components, with exception of VirB1, is absolutely required for secretion of DNA- and/or protein substrates in T4SS. The complete set of VirB-like proteins assembles into a trans-envelope structure functioning as a pilus-building machine, and, upon interaction with the CP (VirD4), becomes a secretion machine for intercellular delivery of proteins and DNA.

\subsection{VirB1: perforation of the peptidoglycan cell wall}

VirB1 belongs to a widespread superfamily of lysozyme-like glycosylases (peptidoglycanases, muramidases) (Koraimann, 2003). Members of this family of enzymes are capable of locally disrupting the Gram-negative peptidoglycan cell wall. Overproduction of the VirB1-like protein P19 of plasmid R1 results in the formation of membrane protrusions and causes cells lysis (Bayer et al., 2001). Removal of VirB1 does not abolish but reduces transfer activity and prevents pilus synthesis (Bayer et al., 1995; Berger and Christie, 1994; Fullner et al., 1996; Lai et al., 2000). Lysis of the cell wall may facilitate the assembly of the Mpf complex.VirB1-like proteins contain an N-terminal signal peptide and localize to the periplasm (Bayer et al., 2000). In case of A. tumefaciens VirB1, the protein is cleaved into two halves once it has reached the periplasm. The N-terminal halve harboring the peptidoglycanase activity remains in the periplasm, whereas the C-terminal halve (VirB1*) is secreted to the exocellular space (Baron et al., 1997a). Both halves of VirB1 independently support the functionality of the VirB/VirD4 secretion system, but the role of VirB1* remains elusive (Llosa et al., 2000). In the Ptl secretion system of $B$. pertussis, a homologue of VirB1 is apparently missing. However, the VirB8-like protein of this secretion system (PtlE) contains an $\mathrm{N}$-terminal domain mediating a VirB1-like peptidoglycanase activity (Rambow-Larsen and Weiss, 2002), suggesting that VirB1 and VirB8 may closely interact in other Mpf systems. Indeed, interactions between VirB1 and VirB8 of A. tumefaciens have been detected in a yeast two-hybrid screen (Ward et al., 2002). The other VirB1 interactions detected in the same screen (Table 2) await validation by biochemical data.

\subsection{VirB2: the structural subunit of pili}

As mentioned above VirB2-like proteins are the structural subunits of pili called pilins. Before secretion to the cell surface, the pilin precursor proteins (100-150 aa in size) undergo several processing steps starting with the cleavage of the N-terminal signal peptide. In case of the F plasmid pilin (TraA) signal peptide cleavage is followed by $\mathrm{N}$-acetylation of the $\mathrm{N}$-terminus (Moore et al., 1993). The pilins of $A$. tumefaciens (VirB2) and RP4 (TrbC) undergo an unusual kind of modification: $\mathrm{N}$ - and $\mathrm{C}$-termini of the precursors form a peptide bond resulting in cyclic proteins, composed of 74 and 78 aa, respectively (Eisenbrandt et al., 1999). In the A. tumefaciens T-pilus, VirB2 forms disulfide-cross-linked homodimers that are important for T-pilus stability (Sagulenko et al., 2001b). Production of pili is probably dispensable in the $B$. pertussis Ptl secretion system, which functions without cell-cell contact and lacks an orthologue of the pilus component VirB5. However, there exists a pilin homologue in the Ptl system (PtlA) which is essential for secretion activity, suggesting that this pilin has an indispensable, yet different role than that of a pilus subunit. Addi- 


\begin{tabular}{|c|c|c|c|c|c|c|c|c|c|c|c|c|}
\hline & VirB1 & VirB2 & VirB3 & VirB4 & VirB5 & VirB6 & VirB7 & VirB8 & VirB9 & VirB10 & VirB11 & VirD4/CP \\
\hline VirB1 & $\mathrm{H}^{1}$ & & & $\mathrm{H}^{1}$ & & & & $\mathrm{G}^{2}, \mathrm{H}^{1}$ & $\mathrm{H}^{1}$ & $\mathrm{H}^{1}$ & $\mathrm{H}^{1}$ & \\
\hline VirB2 & & $B^{3}$ & & & $\mathrm{O}^{4}$ & & $\mathrm{O}^{3}, \mathrm{~B}^{5}$ & & & & & \\
\hline VirB3 & & & & $\mathrm{G}^{6}, \mathrm{O}^{7}$ & $\mathrm{~B}^{8}, \mathrm{H}^{8}$ & & & & & & & \\
\hline VirB4 & $\mathrm{H}^{1}$ & & $G^{6}, O^{7}$ & $H^{1}, B^{9}$ & & & & $H^{1,10}$ & & $\mathrm{H}_{2}^{1,10,11}, \mathrm{~B}^{1}$ & $\mathrm{~B}^{13}, \mathrm{H}^{1}$ & $\mathrm{~B}^{13}, \mathrm{H}^{10}$ \\
\hline VirB5 & & $\mathrm{O}^{4}$ & $\mathrm{~B}^{8}, \mathrm{H}^{8}$ & & & & & & & & & \\
\hline VirB6 & & & & & & & $\mathrm{O}^{5}$ & & & & & \\
\hline VirB7 & & $\mathrm{O}^{3}, \mathrm{~B}^{5}$ & & & & $0^{5}$ & $B^{3,14}$ & & $\begin{array}{c}\mathrm{B}^{14,15,16,17} \\
\mathrm{H}^{1,18,19}\end{array}$ & & & \\
\hline VirB8 & $G^{2}, H^{1}$ & & & $H^{1,10}$ & & & & $H^{19}$ & $\mathrm{~B}_{, \mathrm{O}^{5}}^{19,20} \mathrm{H}^{19}$ & $\mathrm{~B}^{19,20}{ }_{\mathrm{O}^{5}} \mathrm{H}^{19}$ & $\mathrm{H}^{1}$ & \\
\hline VirB9 & $\mathrm{H}^{1}$ & & & & & & $\begin{array}{c}B^{14,15,16,17} \\
H^{1,18,19}\end{array}$ & $\mathrm{~B}_{, \mathrm{O}^{5}}^{19,20}, \mathrm{H}^{19}$ & $\mathrm{H}^{10,19}$ & $\mathrm{~B}_{\mathrm{O}^{5}}^{19,20} \mathrm{H}^{10}$ & $\mathrm{H}^{1,10}$ & \\
\hline VirB10 & $\mathrm{H}^{1}$ & & & $\mathrm{H}_{2}^{1,10,11}, \mathrm{~B}^{1}$ & & & & $\mathrm{~B}^{19,20} \mathrm{O}^{5} \mathrm{H}^{19}$, & $\mathrm{B}^{19,20} \mathrm{O}^{5} \mathrm{H}^{9}$ & $H^{B^{10,19,21}}$ & $\mathrm{H}^{1}$ & $\begin{array}{c}\mathrm{B}^{13,21} \\
\mathrm{H}^{10,21,22}\end{array}$ \\
\hline VirB11 & $\mathrm{H}^{1}$ & & & $\mathrm{~B}^{13}, \mathrm{H}^{1}$ & & & & $\mathrm{H}^{1}$ & $H^{1,10}$ & $\mathrm{H}^{1}$ & $\mathrm{~B}^{23,24}, \mathrm{H}^{11}$ & $B^{13}$ \\
\hline VirD4/CP & & & & $\mathrm{B}^{13}, \mathrm{H}^{10}$ & & & & & & $\begin{array}{l}\mathrm{B}^{13,21} \\
\mathrm{H}^{10,21, \dot{2}^{2}}\end{array}$ & $\mathrm{~B}^{13}$ & $\mathrm{~B}^{25,26}, \mathrm{H}^{27}$ \\
\hline
\end{tabular}

B, detected biochemically (in vitro); $\mathrm{G}$, suggested by genetic arrangement; $\mathrm{H}$, detected by two-hybrid interaction analysis; $\mathrm{O}$, suggested by other indirect evidence. Citations: ${ }^{1}$ Ward et al. (2002); ${ }^{2}$ Rambow-Larsen and Weiss (2002); ${ }^{3}$ Sagulenko et al. (2001b); ${ }^{4}$ Schmidt-Eisenlohr et al. (1999b); ${ }^{5} \mathrm{Krall}$ et al. (2002); ${ }^{6}$ Strauch et al. (2003); ${ }^{7}$ Jones et al. (1994); ${ }^{8}$ Shamaei-Tousi et al. (2004); ${ }^{9}$ Dang et al. (1999); ${ }^{10}$ Malek et al. (2004); ${ }^{11}$ Rain et al. (2001); ${ }^{12}$ Terradot et al. (2004); ${ }^{13}$ Atmakuri et al. (2004); ${ }^{14}$ Spudich et al. (1996); ${ }^{15}$ Anderson et al. (1996); ${ }^{16}$ Farizo et al. (1996); ${ }^{17}$ Harris et al. (2001); ${ }^{18}$ Das et al. (1997); ${ }^{19}$ Das and Xie (2000); ${ }^{20} \mathrm{Kumar}$ and Das (2001); ${ }^{21} \mathrm{Gilmour}$ et al. (2003); ${ }^{22}$ Llosa et al. (2003); ${ }^{23}$ Krause et al. (2000a); ${ }^{24}$ Yeo et al. (2000); ${ }^{25}$ Hormaeche et al. (2002); ${ }^{26}$ Schröder et al. (2002); ${ }^{27}$ Kumar and Das (2002).

${ }^{a}$ All interactions that have been detected so far are listed. Validated and significant interactions are discussed in the text. 
tional indications for a pilus-unrelated function of pilins can be found: amino acid substitution mutants of pilins of conjugation systems were identified that are deficient in pilus production, but proficient in DNA transfer (Eisenbrandt et al., 2000), Furthermore, cell fractionation experiments have shown that VirB2 does not only localize exocellularly to the pilus, but also to the outer and inner membranes of the pilus-producing bacteria (Shirasu and Kado, 1993). It is thus conceivable that pilin, before assembling into an exterior pilus structure, forms a base or "stump" of the pilus that is anchored to the cell envelope. This stump structure is possibly sufficient for substrate transfer. Pilus elongation most probably depends on the presence of the other pilus components VirB5 and VirB7. As outlined below, pilus elongation seems to be controlled by the Mpf components VirB6 and VirB11, which may modulate the Mpf secretion channel for transport of pilus subunits.

\subsection{Vir B3: an outer-membrane component of the $M p f$}

VirB3 is a rather small $(\sim 100 \mathrm{aa})$ component of the Mpf localizing to both the inner and outer membranes, with the majority of the protein localizing to the outer membrane (Shirasu and Kado, 1993). Stable expression of VirB3 requires the presence of the Mpf components VirB4 and VirB6 (Hapfelmeier et al., 2000; Jones et al., 1994). Since VirB4 is also required for targeting of VirB3 to the outer membrane (Jones et al., 1994), it is likely that VirB3 and VirB4 retain a close interaction in the Mpf complex, a presumption supported by the fact that VirB3 and VirB4 are encoded by a single gene (TriC) in case of the Cos100 conjugation system (Strauch et al., 2003). A second interaction partner of VirB3 may be the pilus-associated protein VirB5, which has been detected to interact with VirB3 in a yeast two-hybrid screen, a result which was confirmed by in vitro data (Shamaei-Tousi et al., 2004).

\subsection{VirB4: a motor of secretion embedded in the heart of the secretion machinery?}

VirB4, along with VirB11 and VirD4, is one of the three $\mathrm{Mpf} / \mathrm{CP}$ components that are thought to energize the secretion machinery. Each of these proteins contains the conserved Walker A and B sequence motifs that form a nucleotide-binding site in nucleotide hydrolases (NTPases) (Walker et al., 1982). In the process of type IV secretion, NTPases may convert the chemical energy freed by nucleotide hydrolysis into the kinetic energy needed for translocation of substrates. Mutational analysis of vir $B 4$ has shown that the Walker A and $B$ motifs are indeed essential for functionality of the secretion system (Berger and Christie, 1993; Cook et al., 1999; Fullner et al., 1994; Rabel et al., 2003). T-DNA immunoprecipitation (TrIP) analysis of Walker A motif mutations of VirB4 further revealed that such mutations arrest the transfer of the $A$. tumefaciens T-DNA substrate to the Mpf channel components VirB6 and VirB8 (Atmakuri et al., 2004). However, experiments with several purified VirB4-like proteins failed to detect an NTPase activity in vitro (Rabel et al., 2003), and an early report on VirB4 ATPase activity remains unconfirmed (Shirasu et al., 1994). It is possible that an accessory factor is required to reconstitute the putative NTPase activity of VirB4 in vitro; alternatively, the protein may only bind to nucleotides without hydrolyzing them. Such binding may have a function related to the subsequent (or preceding) hydrolysis of nucleotides by the closely interacting NTPase VirB11 (see below). Binding and/or hydrolysis of nucleotides by VirB4 should allow VirB4 to undergo conformational changes that drive the translocation of secretion substrates and/or pilus subunits.

VirB4-like proteins are the largest of the VirB proteins $(\sim 800-850$ aa) and they localize to the inner membrane. Several observations have led to the view that VirB4 is deeply engaged into protein interactions with other $\mathrm{Mpf} / \mathrm{CP}$ components that take place independently of a functional nucleotide binding/hydrolysis domain (NBD). First, amino acid substitution mutants in the NBD of VirB4 display a negative-dominant phenotype (Berger and Christie, 1993; Dang et al., 1999; Fullner et al., 1994; Rabel et al., 2003). Second, a VirB4-Gfp fusion protein (TrhC of plasmid R27 fused to Gfp) localizes at discrete sites of the cellular membrane, and this localization, although requiring the presence of several Mpf components, does not require a 
functional NBD (Gilmour et al., 2001; Gilmour and Taylor, 2004). Third, the presence of a subset of VirB proteins, including VirB4, enhances the frequency of plasmid uptake when these cells serve as recipients in conjugation experiments with $\mathrm{A}$. tumefaciens (Bohne et al., 1998). This effect requires the presence of the oligomeric form of VirB4 in recipients, whereas it is independent of a functional NBD (Dang et al., 1999). The conclusion is that VirB4 homomultimers are important structural components necessary for the assembly of a robust membrane-spanning channel structure that is potentially capable of transferring DNA bidirectionally. The NBD harboring the NTPase activity is probably required to configure this channel as a dedicated export machine, whereas the remaining domains of VirB4 serve to build a composite Mpf channel structure that is highly dependent on cooperative interactions with other Mpf/CP components. In the conjugation system of the Rhizobium plasmid pNGR324a, the VirB4-like protein seems to be split into two halves: the plasmid encodes two proteins, TrbEa and TrbEb (Freiberg et al., 1997), with homology to the N-terminal (residues 1-137) and C-terminal (residues 161-819) domains of VirB4, respectively. Thus, the $\mathrm{N}$ - and $\mathrm{C}$-terminal domains of VirB4 are likely to fulfill separate functions.

Putative interaction partners of VirB4 are VirB1, VirB8, VirB10, VirB11, and VirD4 (Table 2). These interactions were initially detected in two-hybrid screens (Malek et al., 2004; Rain et al., 2001; Ward et al., 2002) and, in case of VirB10, VirB11, and VirD4, have been validated by in vitro methods (Atmakuri et al., 2004; Terradot et al., 2004). Of special importance are the interactions between the three nucleotide-binding/hydrolyzing components VirB4, VirB11, and VirD4, since these components seem to conjointly energize the transport of the substrate from the cytosol into the membrane-spanning Mpf channel (see below).

\subsection{VirB5: a component of the pilus mediating cell adhesion?}

VirB5 is $\sim 220$ residues in size and contains an $\mathrm{N}$-terminal signal sequence. It localizes extracellularly to the pilus (Schmidt-Eisenlohr et al., 1999a,b), but is also found in cytoplasm and in inner-membrane fractions of pili-producing bacteria (Thorstenson et al., 1993). However, since VirB5 mutants can be complemented extracellularly (Winans and Walker, 1985), the protein's functions are probably only required on the cell surface. For stable expression of VirB5, the presence of VirB6 is needed (Hapfelmeier et al., 2000). The VirB5-like protein of IncN plasmid pKM101 (TraC) has been crystallized, revealing an elongated, $\alpha$-helical structure (Yeo et al., 2003). Structure-based mutagenesis of $\mathrm{TraC}$ has provided some important insights on the function of VirB5like proteins. It was seen that a patch of residues that coincides with the crystallographic molecular interface of two TraC molecules does not mediate TraC dimerization, but instead seems to be important for interactions of TraC with partner proteins (Yeo et al., 2003). In the mutants analyzed, colocalization of $\mathrm{TraC}$ to the pilus was generally an essential requirement for transfer activity and susceptibility to attachment of pilus-specific phages. However, some mutants were identified, which, although localizing to pili and being transfer-positive, did prevent phage attachment, indicating that TraC is normally able to present receptors for phage attachment. In this view, an adhesin-like function, mediating bacterial attachment, has been proposed to be taken over by VirB5 (Yeo et al., 2003). This function of VirB5 perfectly harmonizes with the - initially very skeptically viewed — lack of a VirB5-homologue in the B. pertussis Ptl system. Since the Ptl secretion system exceptionally functions without direct cell-cell contact, the presence of an adhesin should, in this special case, be dispensable, if not even undesirable.

\subsection{VirB6: a modulator of the secretion channel?}

VirB6 is a polytopic inner-membrane protein that forms part of the lumen of the Mpf channel structure, as detected by TrIP analysis in A. tumefaciens (Cascales and Christie, 2004b; Jakubowski et al., 2004). Together with VirB8, VirB6 is required for delivery of the T-DNA substrate to the outermembrane-associated components VirB2 and VirB9 (Cascales and Christie, 2004b). VirB6 of A. tumefaciens localizes to the cell poles, and this localization is dependent on the presence of five 
other Mpf components, VirB7 through VirB11 (Judd et al., 2005). Conversely, the presence of VirB6 is required for stable expression of VirB3 and VirB5 and for formation of VirB7 homodimers and VirB7-VirB9 heterodimers (Hapfelmeier et al., 2000; Jakubowski et al., 2003; Krall et al., 2002). The domains of VirB6 mediating polar localization, interaction with the T-DNA substrate, substrate transfer to VirB8 or substrate transfer to VirB2 and VirB9 have been delimited (Jakubowski et al., 2004; Judd et al., 2005). These data on A. tumefaciens VirB6 clearly demonstrate the importance of VirB6 as a central channel component engaged in a series of substrate- and Mpf-component interactions. The requirement of VirB6 for the stability or functionality of the minor pilus components VirB5 and VirB7 indicates that VirB6 may play an important role in pilus biogenesis or pilus elongation (Hapfelmeier et al., 2000; Jakubowski et al., 2003; Krall et al., 2002). The identification of VirB6 insertion mutants that are deficient in pilus production $\left(\mathrm{Pil}^{-}\right)$but proficient in substrate transfer $\left(\mathrm{Tra}^{+}\right)$(Jakubowski et al., 2003) lends further support to this suggestion. The $\mathrm{Pil}^{-} / \mathrm{Tra}^{+}$phenotype has only been observed in mutants of the pilin (VirB2) and in mutants of VirB6 and VirB11, but not in mutants of any other Mpf/CP component (Jakubowski et al., 2003; Sagulenko et al., 2001a). According to the "stump" model discussed above, the observed $\mathrm{Pil}^{-} / \mathrm{Tra}^{+}$phenotype suggests that it is pilus elongation, but not initial formation of a pilus stump, which is impaired in the identified VirB2, VirB6, and VirB11 mutants. Thus, the native forms of VirB6 and VirB11 may normally control pilus elongation. It can be assumed that this control is achieved by modulating or gating the $\mathrm{Mpf}$ secretion channel for secretion of different substrates: either for components needed for pilus elongation, such as VirB7, or for substrates destined for intercellular delivery.

\subsection{VirB7: a lipoprotein connecting the pilus to the core complex}

VirB7 is a small lipoprotein localizing both to the periplasmic side of the outer membrane and to the extracellular pilus, as observed in A. tumefaciens (Fernandez et al., 1996a; Sagulenko et al., 2001b). In the H. pylori Cag secretion system the
VirB7-homologue (HP0532) localizes to the base of an extracellular, T4SS-dependent filament structure (Rohde et al., 2003; Tanaka et al., 2003). VirB7 of $A$. tumefaciens is required for stable expression of a series of $\mathrm{Mpf}$ components (VirB4, VirB9, VirB10, and VirB11) and also stabilizes the integrity of the T pilus (Beaupré et al., 1997; Fernandez et al., 1996b; Sagulenko et al., 2001b). By tying intermolecular disulfide bridges, VirB7 is able to form homodimers as well as heterodimers with VirB9, an observation which has been made in multiple T4SS (Anderson et al., 1996; Baron et al., 1997b; Das et al., 1997; Farizo et al., 1996; Fernandez et al., 1996b; Harris et al., 2001; Spudich et al., 1996). VirB9, in turn, is an outer-membrane component of the so-called core complex comprising VirB8, VirB9, and VirB10 (see below). Fractionation experiments of detergent-solubilized VirB7containing protein complexes has identified two classes of complexes: one containing the pilus subunit VirB2 and the pilus-associated protein VirB5, and one containing the core complex components VirB8, VirB9, and VirB10 (Krall et al., 2002). Thus, VirB7 may play the role of a connector, attaching the exocellular pilus to the core complex.

\subsection{Vir B8: a bridge over the periplasm representing a nucleation centre for Mpf complex assembly}

VirB8 localizes to the inner membrane, with the majority of the protein exposed to the periplasmic space (Buhrdorf et al., 2003; Das and Xie, 1998; Thorstenson and Zambryski, 1994). In A. tumefaciens, it forms part of the core complex VirB8VirB9-VirB10 (Das and Xie, 2000; Krall et al., 2002; Kumar and Das, 2001) and is needed for proper localization of VirB9 and VirB10 to discrete sites in the bacterial membrane probably representing the sites of Mpf pore complex ( $\mathrm{T}$ complex) assembly (Kumar et al., 2000). Since VirB8, by itself, is able to localize at such discrete sites, VirB8 is thought to play the role of a nucleation centre, recruiting VirB9 and VirB10 to the sites of $\mathrm{T}$ complex assembly (Kumar et al., 2000). The interaction between VirB8, VirB9, and VirB10 establishes a direct bridging of the inner and outer membrane, a key characteristic of T4SS, which are thought to secrete their substrates and/or pilus 
subunits directly from the cytoplasm to the outside, without requiring periplasmic intermediates. The notion of VirB8 through VirB10 representing a core trans-envelope structure is also supported by the finding that homologues of VirB7 through VirB10 in the ComB system of H. pylori are sufficient for mediating DNA uptake (Hofreuter et al., 1998, 2001). Determination of the 3D structure of the core complex could represent a first milestone on the way to resolving the structure of the entire Mpf complex. The first structures of two core complex components (the periplasmic domains of a VirB8 and a VirB10 representative) have recently been solved (Terradot et al., 2005).

Apart from interacting with VirB9 and VirB10, VirB8 probably interacts with VirB1, the Mpf component responsible for degradation of the peptidoglycan. This is suggested by data of a twohybrid screen of $A$. tumefaciens VirB components (Ward et al., 2002) and by the existence in the $B$. pertussis $\mathrm{Ptl}$ system of a single, bifunctional protein harboring both a VirB8- and a VirB1-like domain (Rambow-Larsen and Weiss, 2002). Thus, in addition to recruiting VirB9 and VirB10, VirB8 may be essential for recruiting VirB1 to the site of $\mathrm{Mpf}$ complex assembly, engaging VirB1 for localized peptidoglycan lysis (Ward et al., 2002).

\subsection{VirB9: an outer-membrane anchor of the core complex}

VirB9 of $A$. tumefaciens is present in the inner and the outer membranes, with the majority of the protein co-localizing with VirB8 and VirB10 at discrete sites in the outer membrane (Fernandez et al., 1996a; Kumar et al., 2000; Shirasu and Kado, 1993; Thorstenson et al., 1993). Additionally, VirB9 forms disulfide-bridged complexes with outer-membrane-associated VirB7 that have a stabilizing effect on VirB10 (Beaupré et al., 1997). The role of VirB9 may thus consist in anchoring the core complex to the outer membrane.

\subsection{VirB10: an energy sensor gating the Mpf channel}

The core complex VirB8-VirB9-VirB10 spans the inner and outer membrane, where VirB8 is the inner-membrane anchor and VirB9 is the outermembrane anchor of the complex. VirB10 localizes to both membranes in fractionation experiments (Fernandez et al., 1996a), however, the localization to the outer membrane requires the presence of VirB7 through VirB9 and at least one of the three components VirB1, VirB2, and VirB3 (Liu and Binns, 2003). Apart from associating with VirB8 and VirB9, VirB10 also interacts with the two nucleotide-binding/hydrolyzing components VirB4 and VirD4 (Atmakuri et al., 2004; Gilmour et al., 2003; Llosa et al., 2003; Malek et al., 2004; Rain et al., 2001; Terradot et al., 2004; Ward et al., 2002). Since VirD4, the coupling protein $(\mathrm{CP})$ recruits the substrates to be secreted to the cytoplasmic face of the secretion channel (see below), the VirB10-CP interaction may be crucial at early events initiating substrate transfer. It can be speculated that an external signal, produced upon binding to a recipient cell, is propagated through the core complex and - via VirB10 - communicates to the CP, which then becomes activated for substrate delivery. The domain of VirB10 mediating the interaction with the $\mathrm{CP}$ is contained in the $\mathrm{N}$-terminal halve of VirB10, which is also responsible for VirB10 selfinteractions (Gilmour et al., 2003; Llosa et al., 2003). Remarkably, the VirB10-CP interaction is not system-restricted: VirB10-like proteins can interact, although with lower affinity, with CPs of heterologous T4SS, as suggested by data of a twohybrid interaction analysis (Llosa et al., 2003). The versatility of the VirB10-CP interaction largely explains the functionality of chimeric bacterial conjugation systems containing an Mpf system of one plasmid and a Dtr system of a different plasmid (Bolland et al., 1990; Cabezón et al., 1997; Hamilton et al., 2000).

Protease susceptibility experiments have shown that VirB10 can adopt two different conformations, one of which requiring the presence of cellular ATP (Cascales and Christie, 2004a). Closer inspection has revealed that it is the ATP utilization by VirB11 and VirD4 (but not VirB4) that is responsible for the switch from the ATP-independent to the ATP-dependent "energized" conformation of VirB10 (Cascales and Christie, 2004a). Only the energized conformation of VirB10 is able to form complexes with the outer-membrane 
component VirB9. In contrast, both conformations of VirB10 can interact with VirD4 at the inner membrane. Thus, VirB10 is able to sense and to respond to the energetic status communicated through VirB11 and VirD4. As a consequence VirB10 can either form or disassemble a periplasmic bridge between inner- and outer-membrane components of the Mpf channel (VirB4/VirD4 and VirB9, respectively), which is equivalent to opening or closing the Mpf channel for transfer of substrates.

\subsection{VirB11: a ring-shaped cytoplasmic NTPase fuelling the secretion machinery}

VirB11 belongs to the family of PulE-like NTPases found in type II, type IV and tad-like secretion systems (Motallebi-Veshareh et al., 1992; Planet et al., 2001; Whitchurch et al., 1991). Along with VirB4 and the CP (VirD4), VirB11 is thought to energize the type IV secretion machinery either for complex assembly, pilus production and/or substrate secretion. The NTPase activity of several VirB11-like proteins has been determined in vitro (Christie et al., 1989; Krause et al., 2000b; Rivas et al., 1997; Sexton et al., 2004), revealing a rather weak activity similar to the one observed for chaperons like DnaK (Zylicz et al., 1983). VirB11 of A. tumefaciens has been reported to additionally possess an autophosphorylation activity (Christie et al., 1989), however, such an activity was not detected for any other member of the family of VirB11-like proteins.

The weak NTPase activity of VirB11 can be enhanced by lipid binding, suggesting that, in vivo, localization of VirB11 to the bacterial membrane may stimulate NTPase activity (Krause et al., 2000b; Rivas et al., 1997). More data supporting this assumption have been reported: upon lipid binding, VirB11 is seen to undergo conformational changes (Krause et al., 2000b) and the same effect is also observed for nucleotide binding (Savvides et al., 2003). Moreover, a functional nucleotide binding site is required for localization of VirB11 to the membrane (Sexton et al., 2004). This may be the reason why nucleotide binding motif (Walker A) mutations of VirB11 fail to transfer the T-DNA substrate to the channel components VirB6 and
VirB8, as detected by TrIP analysis in A. tumefaciens (Atmakuri et al., 2004). The finding that VirB11 induces membrane destabilization and hemifusion of lipid vesicles in vitro (Machón et al., 2002) furthermore suggests that VirB11 may function for facilitating membrane insertion of $\mathrm{Mpf}$ proteins that are part of the envelope-spanning Mpf complex. Analysis of the structure of VirB11 (HP0525) has indeed revealed a close structural similarity to other proteins exerting a function involving membrane fusion processes (see below).

Multiple interactions of VirB11 with other Mpf proteins have been detected (Table 2). Yeast-twohybrid studies have identified VirB1, VirB4, VirB8, VirB9, and VirB10 as interaction partners of VirB11 (Malek et al., 2004; Ward et al., 2002). Biochemical evidence has however, only been reported for VirB11-VirB4 and VirB11-VirD4 interactions (Atmakuri et al., 2004). A yeast-twohybrid analysis designed to elucidate interactions of the complete $H$. pylori proteome has proposed a number of non Mpf-encoded interaction partners, most of which are yet to be annotated to biological pathways (Rain et al., 2001). However, a closer inspection of the $H$. pylori protein interaction map uncovers an indirect connection between VirB11 (HP0525) and the secreted toxin of $H$. pylori, CagA (HP0547), since the two proteins appear to be bridged by their interaction partners HP1409 and HP0601 (G. Schröder, personal observation).

The structure of VirB11, as observed by electron microscopy, consists of hexameric rings (Krause et al., 2000a). Crystal structures of the VirB11-like protein HP0525 (H. pylori), either in the unliganded form, or in complex with ADP or the nonhydrolyzable substrate analogue ATP $\gamma \mathrm{S}$, have provided a detailed view on the structural dynamism of VirB11. The structure of ADP-bound or ATP $\gamma$ S-bound HP0525 consists of a dome-like hexameric toroid closed on one end and open on the other (Savvides et al., 2003; Yeo et al., 2000). The subunits of the hexamer contain an N-terminal and a C-terminal domain (NTD and CTD) which sandwich the bound nucleotide and stack as separate rings around the hexameric assembly. The NTDs define the open side (internal diameter of $50 \AA$ ) and the CTDs contribute to a 'six-clawed 
grapple' at the closed end (internal diameter of $10 \AA ̊$ ) of the HP0525 hexamer (Fig. 2). The CTD adopts the RecA fold (Story and Steitz, 1992) typical for ATPases, whereas the fold of the NTD is novel. The structural differences between ADPbound and ATP $\gamma \mathrm{S}$-bound HP0525 are subtle and only consist of local rearrangements in the nucleotide-binding site. A more important difference is the finding that the nucleotide binding sites of HP0525 are not fully occupied in ATP $\gamma$ S-HP0525 crystals, in contrast to the stoichiometric complexes found with ADP. The structure of unliganded HP0525 (Savvides et al., 2003) shows a more dramatic change when compared to the structures of nucleotide-bound HP0525: whereas the CTD ring remains unchanged, the individual NTDs exhibit unequal rigid-body rotations away from the center of the chamber, making the NTD ring asymmetric. Since the NTDs have been identified as mediators of multiple protein interactions by two-hybrid analysis (Rain et al., 2001; Ward et al., 2002), it is conceivable that their flexibility in the nucleotide-free form of HP0525 may be required for efficiently inserting into target binding sites. In summary, the differences between the structures of ADP-bound, ATP $\gamma \mathrm{S}$-bound and nucleotide-free HP0525 have lead to the proposal of a model for the mechanism of sequential binding and hydrolysis by HP0525 (Savvides et al., 2003):

1. The nucleotide free form of HP0525 is an asymmetric hexamer. The CTDs are responsible for holding the subunits together while the NTDs are flexible and may thus bind to target macromolecular complexes.

2. The binding of three ATP molecules locks three subunits into a rigid conformation.

3. Hydrolysis of the three ATPs to ADP with concomitant binding of ATP to the remaining three nucleotide-free subunits results in a perfectly hexameric rigid form.

4. The structure retains its symmetry and rigidity until all ATP molecules are hydrolyzed, at which point HP0525 can return to its nucleotide free form.
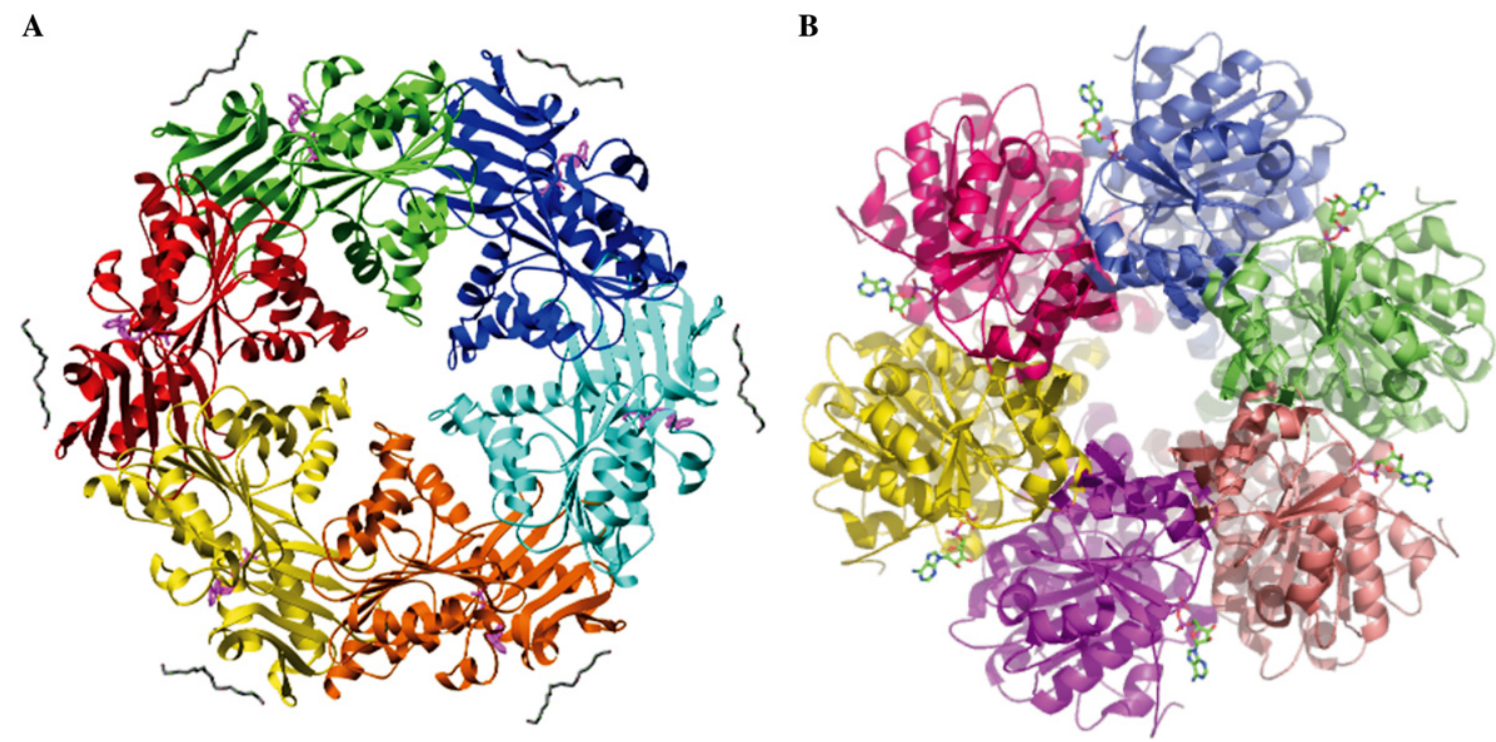

Fig. 2. Structures of VirB11 (HP0525) and VirD4 (TrwB $\Delta$ N70). (A) Ribbon diagram of the HP0525 hexamer in complex with ADP (PDB entry: 1G6O), viewed down the large hole formed by the N-terminal domains. Shown in the periphery of the molecule are polyethylene glycol (PEG) molecules that were components of the crystallization condition and that were found to interact specifically with the protein in the crystal. (B) Ribbon diagram of the TrwB $\Delta$ N70 hexamer in complex with ADP (PDB entry: 1GKI), viewed through the $22 \AA$ mouth of the structure that is expected to face the bacterial membrane. 
Although sequence-unrelated, the structure of HP0525 is remarkably similar to that of the p97 AAA ATPase which, similarly to the related $N$ ethylmaleimide-sensitive fusion protein (NSF), plays a central role in organelle assembly and membrane fusion processes in the endoplasmic reticulum and the Golgi apparatus (Patel and Latterich, 1998; Ye et al., 2001). It has therefore been proposed that VirB11-like proteins, by analogy to p97 and NSF, could serve as mechanical transducers providing the necessary mechanical force for the recruitment/assembly/disassembly of type IV secretion protein components, making them available for insertion into the nascent secretion apparatus and/or to facilitate substrate translocation across the inner membrane (Savvides et al., 2003).

\subsection{CP (VirD4): the cytoplasmic gate to the secretion channel}

The coupling protein $(\mathrm{CP}, \mathrm{VirD} 4$, and TraGlike protein) is an NTP-binding protein that probably contributes to energize the secretion machinery along with VirB4 and VirB11. Similarly to the situation encountered with VirB4, the initially postulated NTPase activity of the CP has not been detected in vitro (Moncalián et al., 1999; Schröder et al., 2002). However, CPs have been demonstrated to bind nucleotides (NTPs) and also nucleotide diphosphates (NDPs) in vitro (Gomis-Rüth et al., 2001; Moncalián et al., 1999; Schröder and Lanka, 2003). Binding and release of nucleotides, which is possibly triggered by $\mathrm{Mg}^{2+}$, may have a mechanistic function related to substrate translocation (Schröder and Lanka, 2003). Mutational analysis of the putative nucleotide binding motifs (Walker A and B 'P-loop' motifs) indicates an essential function of this binding activity for the secretion process (Balzer et al., 1994; Kumar and Das, 2002; Moncalián et al., 1999).

CPs are found in each conjugation system and in most other T4SS, in which they are essential for secretion, but they exceptionally lack in the T4SS of Brucella sp. and B. pertussis. In conjugation, the $\mathrm{CP}$ is required for conjugative DNA transfer, but not for pilus production and mating pair forma- tion (Beijersbergen et al., 1992; Lai et al., 2000). In conjugation experiments with chimeric conjugation systems, composed of Mpf and Dtr systems originating from two different plasmids, the $\mathrm{CP}$ is the factor that determines whether the chimeric machinery is functional or not. By exchanging the $\mathrm{CP}$, the specificity of a given Mpf system for transport of different mobilizable plasmids can be switched, implying that CPs represent an interface between the Mpf complex and the DNA substrate (Cabezón et al., 1994, 1997; Hamilton et al., 2000; Lessl et al., 1993). This conclusion has been validated by biochemical data: CPs of conjugation systems have indeed been detected to directly interact with the relaxase, which is the Dtr component that covalently attaches to the DNA substrate during conjugative transfer (Llosa et al., 2003; Pansegrau and Lanka, 1996b; Schröder et al., 2002; Szpirer et al., 2000). Also, accessory Dtr components such as TraM of the F plasmid (Disqué-Kochem and Dreiseikelmann, 1997), as well as the DNA itself are seen to interact with CPs (Moncalián et al., 1999; Panicker and Minkley, 1992; Schröder and Lanka, 2003; Schröder et al., 2002). Whereas the interactions of the $\mathrm{CP}$ with the protein components of the Dtr system are specific, the binding to DNA is non-sequence-specific, with a preference for single-stranded (ss) DNA (Moncalián et al., 1999; Schröder and Lanka, 2003; Schröder et al., 2002). This indicates that substrate recognition by the $\mathrm{CP}$ primarily occurs via interactions with protein components of the transfer-competent protein/DNA-intermediate. By analogy, the CP of A. tumefaciens, VirD4, interacts with the protein substrate VirE2 (Atmakuri et al., 2003), which is secreted into plant cells independent of T-DNA transfer (Vergunst et al., 2000). The interaction is mediated by the C-terminal domain of VirE2 (Atmakuri et al., 2003). The C-termini of several T4SS-translocated substrates have been identified as the signals mediating secretion by their associated secretion systems (Nagai et al., 2005; Schulein et al., 2005; Simone et al., 2001; Vergunst et al., 2000, 2003, 2005). It therefore seems probable that substrate recognition by the CPs, as a general rule, occurs via specific interactions between the CPs and the $\mathrm{C}$-termini of their associated substrates. 
On the side of the Mpf system, the interaction partners of the CP are VirB4, VirB10, and VirB11 (Atmakuri et al., 2004; Gilmour et al., 2003; Llosa et al., 2003; Malek et al., 2004). These Mpf proteins are inner-membrane components of the envelopespanning Mpf complex. CPs, in turn, are cytoplasmic proteins containing an $\mathrm{N}$-terminal membrane anchor (Das and Xie, 1998; Lee et al., 1999; Schröder et al., 2002). The interaction between the CP and VirB10 has been studied in more detail. In both proteins, the interaction domain was mapped to the N-terminal part containing periplasmic and transmembrane stretches, suggesting that the interaction takes place in the membrane and/or in the periplasm (Gilmour et al., 2003; Llosa et al., 2003). Interestingly, CP-VirB10 interactions can also be detected if the interaction partners originate from two different conjugation systems. The strength of interaction correlates with the efficiency of DNA transfer that is mediated by the chimeric conjugation system, supporting the view that CPs couple the DNA substrate to the Mpf complex (Llosa et al., 2003).

As seen in crystal structures and electron microscopic images of the CP TrwB (plasmid R388), CPs form hexameric ring structures, reminiscent of ring helicases and F1-ATPase (Gomis-Rüth et al., 2001; Hormaeche et al., 2002). Other CPs (TraG of plasmid RP4, TraD of the F plasmid) form higher oligomers, when analyzed in vitro, but they may adopt a similar ring structure in vivo (Schröder et al., 2002). The crystal structure of the cytoplasmic domain of TrwB (TrwB $\Delta$ N70) reveals a rather large $(110 \AA \times 90 \AA)$, globular hexameric assembly composed of intimately associated subunits (Fig. 2). The $\operatorname{TrwB} \Delta \mathrm{N} 70$ hexamer harbors a central channel of $\sim 22 \AA$ but constricts to $\sim 7 \AA$ on the side facing the cytosolic milieu. The TrwB $\Delta$ N70 subunits have the shape of an orange segment and are composed of two linked domains: a highly twisted Rec-A like (Story and Steitz, 1992) $\alpha / \beta$ nucleotide-binding domain (NBD) and a smaller all- $\alpha$ helical domain (AAD). The nucleotide binding sites are formed by superficial cavities at the interfaces between the subunits. The AAD has been proposed to be a putative DNA-binding domain since the AAD of TrwB bears significant similarities with the nucleotide-binding proportion of the site-specific recombinase XerD and with the DNA-binding domain of TraM of plasmid R1 (Gomis-Rüth et al., 2002). The overall structure of TrwB $\Delta$ N70 is remarkably similar to the structure of the $F_{1}$-ATPase $\alpha 3 \beta 3$ heterohexamer (Abrahams et al., 1994) suggesting that T4CPs may also act as molecular motors. Contrary to the dramatic rigidbody domain shifts between nucleotide- and unliganded forms of HP0525 (VirB11), nucleotidebound, and nucleotide-free $\operatorname{TrwB} \Delta \mathrm{N} 70$ exhibits more subtle conformational changes (Gomis-Rüth et al., 2001, 2002). However, these structural rearrangements propagate all the way to the internal channel of the structure, suggesting that nucleotide-binding and/or hydrolysis may serve as a molecular switch facilitating the binding and threading of the protein-linked DNA substrate through the TrwB central channel during conjugation (Gomis-Rüth et al., 2001, 2002). The narrowing of the internal channel at the cytoplasmic face of the hexameric assembly however suggests that additional conformational adjustments must take place for widening this end of the channel, so that passage of the substrate can be achieved.

Removal of the N-terminal membrane anchor of CPs increases their solubility and disrupts their ability to oligomerize in vitro (Hormaeche et al., 2002; Moncalián et al., 1999; Schröder et al., 2002). The monomeric, cytoplasmic domain of the $\mathrm{CP}$ is sufficient for binding nucleotides as well as DNA (Moncalián et al., 1999; Schröder and Lanka, 2003). In contrast, binding to the relaxase substrate requires the presence of the $\mathrm{N}$-terminal membrane anchor, probably because oligomerization of the $\mathrm{CP}$ is essential for relaxase binding (Schröder and Lanka, 2003). In A. tumefaciens, the CP (VirD4) localizes to the cellular poles. Polar localization occurs independently of the presence of other Mpf components and requires both the $\mathrm{N}$-terminal periplasmic domain as well as the nucleotide-binding motif of the protein (Kumar and Das, 2002).

Immunoprecipitation experiments of crosslinked T-DNA complexes (TrIP analysis) in A. tumefaciens have identified the $\mathrm{CP}$ to be the first component of the secretion machinery to contact the DNA substrate on its pathway through the secretion channel (Cascales and Christie, 2004b). The Mpf proteins VirB2, VirB6, VirB8, 
and VirB11, are contacted at a later stage of secretion, since deletion of the $\mathrm{CP}$ prevents the normally detected T-DNA-crosslinks with these components. TrIP analysis in different mutant backgrounds has further identified the hierarchy with respect to T-DNA contact formation, revealing the chronological order of T-DNA contacts with Mpf components during T-DNA transport: after contacting the CP (1), the T-DNA "meets" VirB11 (2), followed by VirB6 and VirB8 (3), and finally VirB2 and VirB9 (4). Accordingly, the CP is the place of departure for the T-DNA substrate on its journey through the secretion pore. Subsequently, the substrate passes to VirB11, where it then enters the membrane-spanning channel, encountering the channel components VirB6 and VirB8. The ultimate T-DNA contacts before transfer of the T-DNA into a recipient cell are formed with the outer-membrane/surface components VirB9 and VirB2. Interestingly, a mutation of the Walker A motif in VirD4 does not prevent T-DNA transfer to VirB11, but instead arrests the transfer from VirB11 to VirB6 and VirB8 (Atmakuri et al., 2004). The same arrested state is observed with Walker A mutations in VirB4 and VirB11, indicating that the three NTP-binding/ hydrolyzing Mpf/CP components VirB4, VirB11, and VirD4 may conjointly energize the transfer of the T-DNA substrate to the channel components VirB6 and VirB8.

In summary, CPs seem to function as a gate to the Mpf secretion channel. Specific interactions between substrate and $\mathrm{CP}$, functioning as key and lock, respectively, may open the gate for transport of the substrates. Co-localization and interaction between each of the three NTP-binding/hydrolyzing components of the Mpf/CP system (VirB4, VirB11, and the CP) indicates that transfer of the substrates is energized in a concerted fashion. This putative three-component motor VirB4/VirB11/CP localizes to the cytoplasmic end of the secretion channel and may utilize NTP-binding and/or NTP-hydrolysis to undergo conformational changes and molecular movements that propagate all the way through the secretion channel, adding up in the transport of substrates across the channel. The exceptional lack of a $\mathrm{CP}$ in the $B$. pertussis T4SS (Ptl) comes along with other unusual fea- tures of this secretion system. Whereas T4SS-mediated secretion across the bacterial membranes is thought to normally function in a single step, the substrate of the Ptl system, the heterooligomeric pertussis toxin (PT), is secreted in two steps. First, the toxin subunits are exported into the periplasmic space, the export being carried out by the Sec system (Locht and Keith, 1986; Nicosia et al., 1986). Next, the subunits assemble into the holotoxin, which then becomes secreted to the exocellular milieu by means of the Ptl type IV secretion machinery (Weiss et al., 1993). It is tempting to speculate that the differences between the $B$. pertussis $\mathrm{Ptl}$ system and the other T4SS exactly reflect the function of the CP, which, similarly to the Sec system, carries out the transport of proteins through the cytoplasmic membrane.

\section{Conjugative relaxases: DNA carrier proteins secreted by the Mpf system}

In conjugation, the transmitted substrate consists of a linear, single-stranded copy of the conjugative or mobilizable plasmid, which, at its $5^{\prime}$ end, is covalently attached to the Dtr-encoded relaxase. Generation of this protein-DNA substrate involves two key events: (1) strand- and site-specific cleavage of the plasmid; (2) generation of a single-stranded DNA (ssDNA) copy of the plasmid as a result of rolling circle-type replication (RCR). Conjugative relaxases initiate the first of these two key events by catalyzing the cleavage at the nic site located within the origin of transfer (oriT) of the plasmid. The reaction occurs via a nucleophilic attack by the hydroxyl group of the relaxase's catalytic tyrosine residue on the $5^{\prime}$ side of the DNA phosphate. This transesterification reaction results in a stable phosphotyrosyl linkage plus a free 3 ' hydroxyl group on the transfer strand of the plasmid [reviewed in (Pansegrau and Lanka, 1996b)].

The relaxase-ssDNA substrate is then secreted unidirectionally (in $5^{\prime}$ to $3^{\prime}$ direction) into a recipient cell. Transfer, carried out by the Mpf/CP machinery, is probably coupled to replication of the plasmid by an RCR mechanism. After transfer of a complete copy of the transfer strand into the recipient cell, the relaxase recognizes the reconsti- 
tuted nic site and undergoes a second transesterification reaction, resulting in recircularization of the transfer strand (Llosa et al., 2002; Pansegrau and Lanka, 1996a). This model view, derived from in vitro studies demonstrating the cleavage/joining reactions of ssDNA strands by the relaxase, has recently been validated by in vivo studies. It was shown that the relaxase (TrwC of plasmid R388) is secreted into the recipient cell in an active form capable of cleaving an oriT substrate resident in the recipient [M. Llosa, communicated on the Plasmid Biology 2004 Meeting (Wegrzyn, 2005)]; moreover, secretion of the relaxases TrwC (R388), MobA (RSF1010), and VirD2 (Ti) was shown to occur independently of DNA transfer (Luo and Isberg, 2004; Vergunst et al., 2005; Wegrzyn, 2005). It can thus be assumed that the process of conjugative DNA transfer relies on secretion of the relaxase as a pilot protein that trails the covalently attached transfer strand. This view is further supported by the finding that the relaxase specifically interacts with the $\mathrm{CP}$ of the $\mathrm{Mpf} / \mathrm{CP}$ secretion machinery (Llosa et al., 2003; Pansegrau and Lanka, 1996b; Schröder et al., 2002; Szpirer et al., 2000), an interaction that is probably essential for initiating the process of secretion. Finally, other type IV secretion systems, which are ancestrally related to the conjugative $\mathrm{Mpf} / \mathrm{CP}$ machinery, are found to secrete protein substrates without any indication for concomitant DNA transfer (Cascales and Christie, 2003; Schröder et al., 2005). The existence of a C-terminal signal mediating translocation of dedicated T4SS protein substrates has been discovered in three different T4SS: the VirB/VirD4 systems of B. henselae and A. tumefaciens, and the Dot/Icm system of L. pneumophila (Atmakuri et al., 2003; Nagai et al., 2005; Schulein et al., 2005; Simone et al., 2001; Vergunst et al., 2000, 2003, 2005). Evidence is accumulating that these secretion systems have evolved from conjugation systems and that the C-terminal secretion signal of their secreted protein substrates originates from a relaxase ancestor (Schulein et al., 2005).

The crystal structures of the relaxase domains of TrwC (R388) and TraI (F) have been determined (Datta et al., 2003; Guasch et al., 2003). They reveal a conserved compact molecular scaff- old possessing features that explain the high affinity and specificity for their respective DNA substrates. The structure consists of a five-strand antiparallel $\beta$-sheet core ('palm' domain), which is flanked by several $\alpha$-helices. The structure of TrwC in complex with a 25-mer oligonucleotide corresponding to the sequence of the transfer strand just upstream of the nic site furthermore provides details of the interactions between the relaxase and its ssDNA substrate (Guasch et al., 2003). This structure corresponds to the situation most probably encountered after cleavage at the nic site. Here, the oligonucleotide forms a double-stranded hairpin followed by a single-stranded portion that ends in a closed pocket including the active site of TrwC. The closed structure at the nic site implies that the relaxase must undergo a conformational change in this region to allow exchange of cleaved and uncleaved ssDNA. Structure determination of a DNA-complexed relaxase, residing in the state prior to nic cleavage, is needed to gain more insights into the detailed mechanism of ssDNA cleavage.

The active sites of TraI and TrwC contain a catalytic tyrosine residue and a divalent metal ion. Possible roles for the metal cation consist in polarizing the scissile phosphate of the ssDNA substrate for facilitating the nucleophilic attack by the catalytic tyrosine hydroxyl group, and of stabilizing the ensuing transition state. An aspartate residue in TrwC has been proposed as a candidate general base that could activate the catalytic tyrosine by proton abstraction (Guasch et al., 2003). TraI and TrwC each contain a second tyrosine residue which is thought to catalyze the second DNA strand transfer reaction that recircularizes the plasmid after one round of transfer (Grandoso et al., 2000; Pansegrau and Lanka, 1996b). Following the paradigm of ssDNA bacteriophage replication (Hanai and Wang, 1993; van Mansfeld et al., 1986), the mechanism may involve a "flip-flop" reaction allowing efficient recircularization and transfer of multiple copies of the plasmid, without need for reinitiation of the oriT-relaxase complex. Consistent with this view, the two catalytic tyrosine residues of TraI, although not far separated, localize on opposite faces of the protein. This may be a necessary feature for enabling DNA cleavage by the second 
tyrosine residue, while the first tyrosine residue is still covalently attached to the DNA strand.

\section{Conclusions}

The $\mathrm{Mpf} / \mathrm{CP}$ secretion machinery is a large trans-envelope structure that enables intercellular delivery of proteins and DNA. Particular functions have been assigned to most of the individual components of this secretion machinery (Fig. 3). The power unit consists of a three-component engine, VirB4/VirB11/VirD4, which, fuelled by nucleotides, energizes the transport of dedicated substrates from the cytoplasmic/inner-membrane end of the secretion channel. Here, VirD4 is the specificity determinant for substrate recognition. VirB8/ VirB9/VirB10 form the core complex of the secretion channel: VirB8 is a periplasmic nucleation centre for complex assembly; VirB10 senses the energetic state of VirB11 and VirD4 and responds to it by closing or opening the periplasmic gap to VirB9, which is the outer-membrane anchor of the core complex. A second outer-membrane component of the Mpf/CP complex is VirB3. For facilitating complex assembly, the peptidoglycanase VirB1 mills out the peptidoglycan layer. VirB6 controls the secretion channel and modulates it for secretion of different substrate molecules. The lipoprotein VirB7 connects the core complex to the exocellular pilus, which is mainly composed of VirB2 subunits. The pilus is needed for sensing and capturing a potential recipient cell; for this, the pilus-associated putative adhesin VirB5 is thought to attach to receptors of the recipient cell.

In 1991, the EMBO meeting report on "Bacterial Conjugation Systems," organized by Erich Lanka and Brian Wilkins, ended with the following set of questions (Lanka and Wilkins, 1991): "What in vivo signal triggers oriT cleavage and

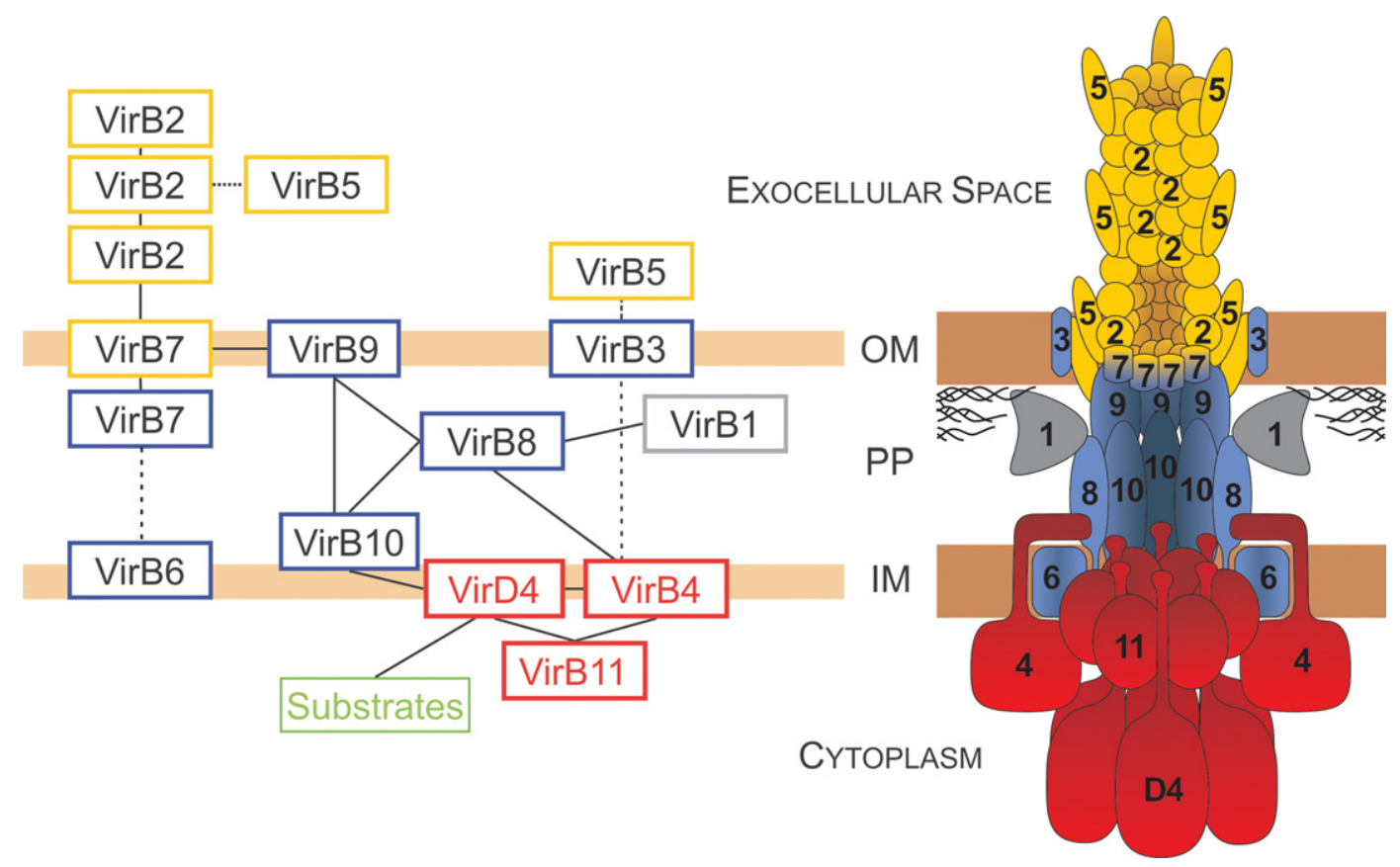

Fig. 3. Architecture of the type IV secretion machinery. Model view of the type IV secretion apparatus composed of energizers (red), core complex components (blue), peptidoglycanases (grey), and surface-exposed components (yellow). The subunits are named according to the VirB/VirD4 secretion system of $A$. tumefaciens. (Left) Interactions that have been detected experimentally are schematically shown by connections between the components. (Right) Assembly of the data set of known interactions, along with the available data on the relative sizes, the membrane localization and topology, the oligomeric states, the structures and the functions, leads to a model view of the architecture of the complete $\mathrm{Mpf} / \mathrm{CP}$ secretion machinery. Mechanistic models are discussed in the text. 
transfer replication? What is the nature of the DNA transport pore and the role of the conjugative pilus? Once we saw clearly, now we see through a glass darkly!" Some of these fundamental questions have meanwhile been answered and the picture of the transport pore has become clearer. However, other questions, like the one regarding the cleavage trigger, still remain very up to date. On the other hand, we are now able to ask more specific questions: how does NTP hydrolysis drive the translocation of the substrates on the molecular level? What molecular switch turns the secretion machinery on or off? How is the membrane barrier of the targeted host cell penetrated? The appearance of conjugation-related secretion systems (T4SS) associated with pathogenesis has imposed a series of application-oriented questions: what can we learn from conjugation to understand toxin secretion? How can we use this knowledge to specifically inhibit T4SS or to use T4SS as specific tools for protein and/or DNA secretion into eukaryotes? As it is a general rule in science, answers give rise to new questions. It will be interesting to follow where conjugation will lead us to in the future.

\section{Acknowledgments}

We thank C.M. Thomas and D.K. Chattoraj for giving the initiative of writing this review after G.S. having presented a lecture on the $\mathrm{Mpf} / \mathrm{CP}$ system on the "Plasmid Biology 2004" meeting in Corfu, Greece. Financial support was given by the Swiss National Science Foundation (SNF) to G.S.

\section{References}

Abrahams, J.P., Leslie, A.G., Lutter, R., Walker, J.E., 1994. Structure at 2. 8 A resolution of F1-ATPase from bovine heart mitochondria. Nature 370, 621-628.

Achtman, M., Kennedy, N., Skurray, R., 1977. Cell-cell interactions in conjugating Escherichia coli: role of traT protein in surface exclusion. Proc. Natl. Acad. Sci. USA 74, 51045108.

Achtman, M., Morelli, G., Schwuchow, S., 1978a. Cell-cell interactions in conjugating Escherichia coli: role of $\mathrm{F}$ pili and fate of mating aggregates. J. Bacteriol. 135, 1053-1061.
Achtman, M., Schwuchow, S., Helmuth, R., Morelli, G., Manning, P.A., 1978b. Cell-cell interactions in conjugating Escherichia coli: $\mathrm{Con}^{-}$mutants and stabilization of mating aggregates. Mol. Gen. Genet. 164, 171-183.

Anderson, L.B., Hertzel, A.V., Das, A., 1996. Agrobacterium tumefaciens VirB7 and VirB9 form a disulfide-linked protein complex. Proc. Natl. Acad. Sci. USA 93, 8889-8894.

Andersson, S.G., Zomorodipour, A., Andersson, J.O., SicheritzPonten, T., Alsmark, U.C., Podowski, R.M., Naslund, A.K., Eriksson, A.S., Winkler, H.H., Kurland, C.G., 1998. The genome sequence of Rickettsia prowazekii and the origin of mitochondria. Nature 396, 133-140.

Anthony, K.G., Sherburne, C., Sherburne, R., Frost, L.S., 1994. The role of the pilus in recipient cell recognition during bacterial conjugation mediated by F-like plasmids. Mol. Microbiol. 13, 939-953.

Atmakuri, K., Cascales, E., Christie, P.J., 2004. Energetic components VirD4, VirB11 and VirB4 mediate early DNA transfer reactions required for bacterial type IV secretion. Mol. Microbiol. 54, 1199-1211.

Atmakuri, K., Ding, Z., Christie, P.J., 2003. VirE2, a type IV secretion substrate, interacts with the VirD4 transfer protein at cell poles of Agrobacterium tumefaciens. Mol. Microbiol. 49, 1699-1713.

Backert, S., Churin, Y., Meyer, T.F., 2002. Helicobacter pylori type IV secretion, host cell signalling and vaccine development. Keio J. Med. 51 (Suppl. 2), 6-14.

Bacon, D.J., Alm, R.A., Burr, D.H., Hu, L., Kopecko, D.J., Ewing, C.P., Trust, T.J., Guerry, P., 2000. Involvement of a plasmid in virulence of Campylobacter jejuni 81-176. Infect. Immun. 68, 4384-4390.

Bacon, D.J., Alm, R.A., Hu, L., Hickey, T.E., Ewing, C.P., Batchelor, R.A., Trust, T.J., Guerry, P., 2002. DNA sequence and mutational analyses of the pVir plasmid of Campylobacter jejuni 81-176. Infect. Immun. 70, 6242-6250.

Balzer, D., Pansegrau, W., Lanka, E., 1994. Essential motifs of relaxase (TraI) and TraG proteins involved in conjugative transfer of plasmid RP4. J. Bacteriol. 176, 4285-4295.

Baron, C., Llosa, M., Zhou, S., Zambryski, P.C., 1997a. VirB1, a component of the T-complex transfer machinery of Agrobacterium tumefaciens, is processed to a $\mathrm{C}$-terminal secreted product, VirB1*. J. Bacteriol. 179, 1203-1210.

Baron, C., Thorstenson, Y.R., Zambryski, P.C., 1997b. The lipoprotein VirB7 interacts with VirB9 in the membranes of Agrobacterium tumefaciens. J. Bacteriol. 179, 1211-1218.

Bayer, M., Bischof, K., Noiges, R., Koraimann, G., 2000. Subcellular localization and processing of the lytic transglycosylase of the conjugative plasmid R1. FEBS Lett. 466, 389393.

Bayer, M., Eferl, R., Zellnig, G., Teferle, A., Dijkstra, A., Koraimann, G., Högenauer, G., 1995. Gene 19 of plasmid R1 is required both for efficient conjugative transfer and bacteriophage R17 infection. J. Bacteriol. 177, 4279-4288.

Bayer, M., Iberer, R., Bischof, K., Rassi, E., Stabentheiner, E., Zellnig, G., Koraimann, G., 2001. Functional and mutational analysis of p19, a DNA transfer protein with muramidase activity. J. Bacteriol. 183, 3176-3183. 
Beaupré, C.E., Bohne, J., Dale, E.M., Binns, A.N., 1997. Interactions between VirB9 and VirB10 membrane proteins involved in movement of DNA from Agrobacterium tumefaciens into plant cells. J. Bacteriol. 179, 78-89.

Beijersbergen, A., Den Dulk-Ras, A., Schilperoort, R.A., Hooykaas, P.J.J., 1992. Conjugative transfer by the virulence system of Agrobacterium tumefaciens. Science 256, 1324-1327.

Berger, B.R., Christie, P.J., 1993. The Agrobacterium tumefaciens vir $B 4$ gene-product is an essential virulence protein requiring an intact nucleoside triphosphate-binding domain. J. Bacteriol. 175, 1723-1734.

Berger, B.R., Christie, P.J., 1994. Genetic complementation analysis of the Agrobacterium tumefaciens virB operonvirB2 through virB11 are essential virulence genes. J. Bacteriol. 176, 3646-3660.

Bohne, J., Yim, A., Binns, A.N., 1998. The Ti plasmid increases the efficiency of Agrobacterium tumefaciens as a recipient in virB-mediated conjugal transfer of an IncQ plasmid. Proc. Natl. Acad. Sci. USA 95, 7057-7062.

Bolland, S., Llosa, M., Avila, P., de la Cruz, F., 1990. General organization of the conjugal transfer genes of the IncW plasmid R388 and interactions between R388 and IncN and IncP plasmids. J. Bacteriol. 172, 5795-5802.

Boschiroli, M.L., Ouahrani-Bettache, S., Foulongne, V., Michaux-Charachon, S., Bourg, G., Allardet-Servent, A., Cazevieille, C., Lavigne, J.P., Liautard, J.P., Ramuz, M., O'Callaghan, D., 2002. Type IV secretion and Brucella virulence. Vet. Microbiol. 90, 341-348.

Buhrdorf, R., Förster, C., Haas, R., Fischer, W., 2003. Topological analysis of a putative $\operatorname{vir} B 8$ homologue essential for the cag type IV secretion system in Helicobacter pylori. Int. J. Med. Microbiol. 293, 213-217.

Cabezón, E., Lanka, E., de la Cruz, F., 1994. Requirements for mobilization of plasmids RSF1010 and ColE1 by the IncW plasmid R388: trwB and RP4 traG are interchangeable. J. Bacteriol. 176, 4455-4458.

Cabezón, E., Sastre, J.I., de la Cruz, F., 1997. Genetic evidence of a coupling role for the TraG protein family in bacterial conjugation. Mol. Gen. Genet. 254, 400-406.

Cascales, E., Christie, P.J., 2003. The versatile bacterial type IV secretion systems. Nat. Rev. Microbiol. 1, 137-149.

Cascales, E., Christie, P.J., 2004a. Agrobacterium VirB10, an ATP energy sensor required for type IV secretion. Proc. Natl. Acad. Sci. USA 101, 17228-17233.

Cascales, E., Christie, P.J., 2004b. Definition of a bacterial type IV secretion pathway for a DNA substrate. Science 304, 1170-1173.

Celli, J., Gorvel, J.P., 2004. Organelle robbery: Brucella interactions with the endoplasmic reticulum. Curr. Opin. Microbiol. 7, 93-97.

Charpentier, E., Gerbaud, G., Courvalin, P., 1999. Conjugative mobilization of the rolling-circle plasmid pIP823 from Listeria monocytogenes BM4293 among gram-positive and gramnegative bacteria. J. Bacteriol. 181, 3368-3374.

Chen, J., de Felipe, K.S., Clarke, M., Lu, H., Anderson, O.R., Segal, G., Shuman, H.A., 2004. Legionella effectors that promote nonlytic release from protozoa. Science 303, 1358-1361.
Christie, P.J., 2004. Type IV secretion: the Agrobacterium VirB/ D4 and related conjugation systems. Biochim. Biophys. Acta 1694, 219-234.

Christie, P.J., Ward Jr., J.E., Gordon, M.P., Nester, E.W., 1989. A gene required for transfer of T-DNA to plants encodes an ATPase with autophosphorylating activity. Proc. Natl. Acad. Sci. USA 86, 9677-9681.

Conover, G.M., Derre, I., Vogel, J.P., Isberg, R.R., 2003. The Legionella pneumophila LidA protein: a translocated substrate of the Dot/Icm system associated with maintenance of bacterial integrity. Mol. Microbiol. 48, 305-321.

Cook, D.M., Farizo, K.M., Burns, D.L., 1999. Identification and characterization of PtlC, an essential component of the pertussis toxin secretion system. Infect. Immun. 67, 754-759.

Curtiss III, R., 1969. Bacterial conjugation. Annu. Rev. Microbiol. 23, 69-136.

Dang, T.A., Zhou, X.R., Graf, B., Christie, P.J., 1999. Dimerization of the Agrobacterium tumefaciens VirB4 ATPase and the effect of ATP-binding cassette mutations on the assembly and function of the T-DNA transporter. Mol. Microbiol. $32,1239-1253$.

Das, A., Anderson, L.B., Xie, Y.H., 1997. Delineation of the interaction domains of Agrobacterium tumefaciens VirB7 and VirB9 by use of the yeast two-hybrid assay. J. Bacteriol. 179, 3404-3409.

Das, A., Xie, Y.H., 1998. Construction of transposon Tn3phoA: its application in defining the membrane topology of the Agrobacterium tumefaciens DNA transfer proteins. Mol. Microbiol. 27, 405-414.

Das, A., Xie, Y.H., 2000. The Agrobacterium T-DNA transport pore proteins VirB8, VirB9, and VirB10 interact with one another. J. Bacteriol. 182, 758-763.

Datta, S., Larkin, C., Schildbach, J.F., 2003. Structural insights into single-stranded DNA binding and cleavage by $\mathrm{F}$ factor TraI. Structure (Camb.) 11, 1369-1379.

Dehio, C., 2004. Molecular and cellular basis of Bartonella pathogenesis. Annu. Rev. Microbiol. 58, 365-390.

Disqué-Kochem, C., Dreiseikelmann, B., 1997. The cytoplasmic DNA-binding protein TraM binds to the inner membrane protein TraD in vitro. J. Bacteriol. 179, 6133-6137.

Dürrenberger, M.B., Villiger, W., Bächi, T., 1991. Conjugational junctions: morphology of specific contacts in conjugating Escherichia coli bacteria. J. Struct. Biol. 107, 146-156.

Eisenbrandt, R., Kalkum, M., Lai, E.M., Lurz, R., Kado, C.I., Lanka, E., 1999. Conjugative pili of IncP plasmids, and the Ti plasmid $\mathrm{T}$ pilus are composed of cyclic subunits. J. Biol. Chem. 274, 22548-22555.

Eisenbrandt, R., Kalkum, M., Lurz, R., Lanka, E., 2000. Maturation of IncP pilin precursors resembles the catalytic Dyad-like mechanism of leader peptidases. J. Bacteriol. 182, 6751-6761.

Farizo, K.M., Cafarella, T.G., Burns, D.L., 1996. Evidence for a ninth gene, ptlI, in the locus encoding the pertussis toxin secretion system of Bordetella pertussis and formation of a PtlI-PtlF complex. J. Biol. Chem. 271, 31643-31649.

Fernandez, D., Dang, T.A., Spudich, G.M., Zhou, X.R., Berger, B.R., Christie, P.J., 1996a. The Agrobacterium tumefaciens virB7 gene product, a proposed component of the T-com- 
plex transport apparatus, is a membrane-associated lipoprotein exposed at the periplasmic surface. J. Bacteriol. 178, 3156-3167.

Fernandez, D., Spudich, G.M., Zhou, X.R., Christie, P.J., 1996b. The Agrobacterium tumefaciens VirB7 lipoprotein is required for stabilization of VirB proteins during assembly of the T-complex transport apparatus. J. Bacteriol. 178, 3168-3176.

Freiberg, C., Fellay, R., Bairoch, A., Broughton, W.J., Rosenthal, A., Perret, X., 1997. Molecular basis of symbiosis between Rhizobium and legumes. Nature 387, 394401.

Frost, L.S., 1993. Conjugative pili and pilus-specific phages. In: Clewell, D.B. (Ed.), Bacterial Conjugation. Plenum Press, New York, pp. 189-221.

Fullner, K.J., Lara, J.C., Nester, E.W., 1996. Pilus assembly by Agrobacterium T-DNA transfer genes. Science 273, 11071109.

Fullner, K.J., Stephens, K.M., Nester, E.W., 1994. An essential virulence protein of Agrobacterium tumefaciens, VirB4, requires an intact mononucleotide binding domain to function in transfer of T-DNA. Mol. Gen. Genet. 245, 704-715.

Gilmour, M.W., Taylor, D.E., 2004. A subassembly of R27encoded transfer proteins is dependent on TrhC nucleoside triphosphate-binding motifs for function but not formation. J. Bacteriol. 186, 1606-1613.

Gilmour, M.W., Gunton, J.E., Lawley, T.D., Taylor, D.E., 2003. Interaction between the IncHI1 plasmid R27 coupling protein and type IV secretion system: TraG associates with the coiled-coil mating pair formation protein TrhB. Mol. Microbiol. 49, 105-116.

Gilmour, M.W., Lawley, T.D., Rooker, M.M., Newnham, P.J., Taylor, D.E., 2001. Cellular location and temperaturedependent assembly of IncHI1 plasmid R27-encoded TrhCassociated conjugative transfer protein complexes. Mol. Microbiol. 42, 705-715.

Gomis-Rüth, F.X., Moncalián, G., de la Cruz, F., Coll, M., 2002. Conjugative plasmid protein TrwB, an integral membrane type IV secretion system coupling protein. Detailed structural features and mapping of the active site cleft. J. Biol. Chem. 277, 7556-7566.

Gomis-Rüth, F.X., Moncalián, G., Perez-Luque, R., Gonzalez, A., Cabezón, E., de la Cruz, F., Coll, M., 2001. The bacterial conjugation protein TrwB resembles ring helicases and F1ATPase. Nature 409, 637-641.

Gormley, E.P., Davis, J., 1991. Transfer of plasmid RSF1010 by conjugation from Escherichia coli to Streptomyces lividans and Mycobacterium smegmatis. J. Bacteriol. 173, 67056708.

Grandoso, G., Avila, P., Cayon, A., Hernando, M.A., Llosa, M., de la Cruz, F., 2000. Two active-site tyrosyl residues of protein TrwC act sequentially at the origin of transfer during plasmid R388 conjugation. J. Mol. Biol. 295, 1163-1172.

Guasch, A., Lucas, M., Moncalián, G., Cabezas, M., PérezLuque, R., Gomis-Rüth, F.X., de la Cruz, F., Coll, M., 2003. Recognition and processing of the origin of transfer DNA by conjugative relaxase TrwC. Nat. Struct. Biol. 10, 10021010.
Haase, J., Kalkum, M., Lanka, E., 1996. TrbK, a small cytoplasmic membrane lipoprotein, functions in entry exclusion of the IncP alpha plasmid RP4. J. Bacteriol. 178, 6720-6729.

Hamilton, C.M., Lee, H., Li, P.L., Cook, D.M., Piper, K.R., von Bodman, S.B., Lanka, E., Ream, W., Farrand, S.K., 2000. TraG from RP4 and TraG and VirD4 from Ti plasmids confer relaxosome specificity to the conjugal transfer system of pTiC58. J. Bacteriol. 182, 1541-1548.

Hanai, R., Wang, J.C., 1993. The mechanism of sequence-specific DNA cleavage and strand transfer by phi X174 gene $A^{*}$ protein. J. Biol. Chem. 268, 23830-23836.

Hapfelmeier, S., Domke, N., Zambryski, P.C., Baron, C., 2000. VirB6 is required for stabilization of VirB5 and VirB3 and formation of VirB7 homodimers in Agrobacterium tumefaciens. J. Bacteriol. 182, 4505-4511.

Harris, R.L., Hombs, V., Silverman, P.M., 2001. Evidence that F-plasmid proteins TraV, TraK and TraB assemble into an envelope-spanning structure in Escherichia coli. Mol. Microbiol. 42, 757-766.

Heinemann, J.A., Sprague Jr., G.F., 1989. Bacterial conjugative plasmids mobilize DNA transfer between bacteria and yeast. Nature 340, 205-209.

Hofreuter, D., Odenbreit, S., Haas, R., 2001. Natural transformation competence in Helicobacter pylori is mediated by the basic components of a type IV secretion system. Mol. Microbiol. 41, 379-391.

Hofreuter, D., Odenbreit, S., Henke, G., Haas, R., 1998. Natural competence for DNA transformation in Helicobacter pylori: identification and genetic characterization of the $\operatorname{comB}$ locus. Mol. Microbiol. 28, 1027-1038.

Hormaeche, I., Alkorta, I., Moro, F., Valpuesta, J.M., Goñi, F.M., de la Cruz, F., 2002. Purification and properties of TrwB, a hexameric, ATP-binding integral membrane protein essential for R388 plasmid conjugation. J. Biol. Chem. 277, 46456-46462.

Hwang, H.H., Gelvin, S.B., 2004. Plant proteins that interact with VirB2, the Agrobacterium tumefaciens pilin protein, mediate plant transformation. Plant Cell 16, 3148-3167.

Jakubowski, S.J., Krishnamoorthy, V., Cascales, E., Christie, P.J., 2004. Agrobacterium tumefaciens VirB6 domains direct the ordered export of a DNA substrate through a type IV secretion system. J. Mol. Biol. 341, 961-977.

Jakubowski, S.J., Krishnamoorthy, V., Christie, P.J., 2003. Agrobacterium tumefaciens VirB6 protein participates in formation of VirB7 and VirB9 complexes required for type IV secretion. J. Bacteriol. 185, 2867-2878.

Jones, A.L., Shirasu, K., Kado, C.I., 1994. The product of the virB4 gene of Agrobacterium tumefaciens promotes accumulation of VirB3 protein. J. Bacteriol. 176, 5255-5261.

Judd, P.K., Kumar, R.B., Das, A., 2005. The type IV secretion apparatus protein VirB6 of Agrobacterium tumefaciens localizes to a cell pole. Mol. Microbiol. 55, 115-124.

Koraimann, G., 2003. Lytic transglycosylases in macromolecular transport systems of Gram-negative bacteria. Cell. Mol. Life Sci. 60, 2371-2388.

Krall, L., Wiedemann, U., Unsin, G., Weiss, S., Domke, N., Baron, C., 2002. Detergent extraction identifies different 
VirB protein subassemblies of the type IV secretion machinery in the membranes of Agrobacterium tumefaciens. Proc. Natl. Acad. Sci. USA 99, 11405-11410.

Krause, S., Bárcena, M., Pansegrau, W., Lurz, R., Carazo, J.M., Lanka, E., 2000a. Sequence-related protein export NTPases encoded by the conjugative transfer region of RP4 and by the cag pathogenicity island of Helicobacter pylori share similar hexameric ring structures. Proc. Natl. Acad. Sci. USA 97, 3067-3072.

Krause, S., Pansegrau, W., Lurz, R., de la Cruz, F., Lanka, E., 2000b. Enzymology of type IV macromolecule secretion systems: the conjugative transfer regions of plasmids RP4 and R388 and the cag pathogenicity island of Helicobacter pylori encode structurally and functionally related nucleoside triphosphate hydrolases. J. Bacteriol. 182, 2761-2770.

Kumar, R.B., Das, A., 2001. Functional analysis of the Agrobacterium tumefaciens T-DNA transport pore protein VirB8. J. Bacteriol. 183, 3636-3641.

Kumar, R.B., Das, A., 2002. Polar location and functional domains of the Agrobacterium tumefaciens DNA transfer protein VirD4. Mol. Microbiol. 43, 1523-1532.

Kumar, R.B., Xie, Y.H., Das, A., 2000. Subcellular localization of the Agrobacterium tumefaciens T-DNA transport pore proteins: VirB8 is essential for the assembly of the transport pore. Mol. Microbiol. 36, 608-617.

Kurenbach, B., Bohn, C., Prabhu, J., Abudukerim, M., Szewzyk, U., Grohmann, E., 2003. Intergeneric transfer of the Enterococcus faecalis plasmid pIP501 to Escherichia coli and Streptomyces lividans and sequence analysis of its tra region. Plasmid 50, 86-93.

Lai, E.M., Kado, C.I., 1998. Processed VirB2 is the major subunit of the promiscuous pilus of Agrobacterium tumefaciens. J. Bacteriol. 180, 2711-2717.

Lai, E.M., Kado, C.I., 2000. The T-pilus of Agrobacterium tumefaciens. Trends Microbiol. 8, 361-369.

Lai, E.-M., Chesnokova, O., Banta, L.M., Kado, C.I., 2000. Genetic and environmental factors affecting T-pilin export and T-pilus biogenesis in relation to flagellation of Agrobacterium tumefaciens. J. Bacteriol. 182, 3705-3716.

Lanka, E., Wilkins, B., 1991. Sex, promiscuity, and the bacterial cell. Bacterial Conjugation Systems sponsored by the European Molecular Biology Organization, Schloss Ringberg, Germany, June 30-July 4, 1991. New Biol. 3, 1035 1039.

Lawley, T.D., Gordon, G.S., Wright, A., Taylor, D.E., 2002. Bacterial conjugative transfer: visualization of successful mating pairs and plasmid establishment in live Escherichia coli. Mol. Microbiol. 44, 947-956.

Lawley, T.D., Klimke, W.A., Gubbins, M.J., Frost, L.S., 2003. F factor conjugation is a true type IV secretion system. FEMS Microbiol. Lett. 224, 1-15.

Lederberg, J., Tatum, E., 1946. Gene recombination in E. coli. Nature 158, 558.

Lee, M.H., Kosuk, N., Bailey, J., Traxler, B., Manoil, C., 1999. Analysis of $\mathrm{F}$ factor TraD membrane topology by use of gene fusions and trypsin-sensitive insertions. J. Bacteriol. $181,6108-6113$.
Lessl, M., Lanka, E., 1994. Common mechanisms in bacterial conjugation and Ti-mediated T-DNA transfer to plant cells. Cell 77, 321-324.

Lessl, M., Pansegrau, W., Lanka, E., 1992. Relationship of DNA-transfer-systems: essential transfer factors of plasmids RP4, Ti and F share common sequences. Nucleic Acids Res. 20, 6099-6100.

Less1, M., Balzer, D., Weyrauch, K., Lanka, E., 1993. The mating pair formation system of plasmid RP4 defined by RSF1010 mobilization and donor-specific phage propagation. J. Bacteriol. 175, 6415-6425.

Liu, Z., Binns, A.N., 2003. Functional subsets of the virB type IV transport complex proteins involved in the capacity of Agrobacterium tumefaciens to serve as a recipient in virBmediated conjugal transfer of plasmid RSF1010. J. Bacteriol. 185, 3259-3269.

Llosa, M., Gomis-Rüth, F.X., Coll, M., de la Cruz, F., 2002. Bacterial conjugation: a two-step mechanism for DNA transport. Mol. Microbiol. 45, 1-8.

Llosa, M., Zunzunegui, S., de la Cruz, F., 2003. Conjugative coupling proteins interact with cognate and heterologous VirB10-like proteins while exhibiting specificity for cognate relaxosomes. Proc. Natl. Acad. Sci. USA 100, 10465-10470.

Llosa, M., Zupan, J., Baron, C., Zambryski, P., 2000. The N- and C-terminal portions of the Agrobacterium VirB1 protein independently enhance tumorigenesis. J. Bacteriol. 182, 3437-3445.

Locht, C., Keith, J.M., 1986. Pertussis toxin gene: nucleotide sequence and genetic organization. Science 232, 12581264.

Luo, Z.Q., Isberg, R.R., 2004. Multiple substrates of the Legionella pneumophila Dot/Icm system identified by interbacterial protein transfer. Proc. Natl. Acad. Sci. USA 101, 841-846.

Machón, C., Rivas, S., Albert, A., Goñi, F.M., de la Cruz, F., 2002. TrwD, the hexameric traffic ATPase encoded by plasmid R388, induces membrane destabilization and hemifusion of lipid vesicles. J. Bacteriol. 184, 1661-1668.

Malek, J.A., Wierzbowski, J.M., Tao, W., Bosak, S.A., Saranga, D.J., Doucette-Stamm, L., Smith, D.R., McEwan, P.J., McKernan, K.J., 2004. Protein interaction mapping on a functional shotgun sequence of Rickettsia sibirica. Nucleic Acids Res. 32, 1059-1064.

Masui, S., Sasaki, T., Ishikawa, H., 2000. Genes for the type IV secretion system in an intracellular symbiont, Wolbachia, a causative agent of various sexual alterations in arthropods. J. Bacteriol. 182, 6529-6531.

Matthysse, A.G., 1987. Characterization of nonattaching mutants of Agrobacterium tumefaciens. J. Bacteriol. 169, 313-323.

Moncalián, G., Cabezón, E., Alkorta, I., Valle, M., Moro, F., Valpuesta, J.M., Goñi, F.M., de la Cruz, F., 1999. Characterization of ATP and DNA binding activities of TrwB, the coupling protein essential in plasmid R388 conjugation. J. Biol. Chem. 274, 36117-36124.

Moore, D., Hamilton, C.M., Maneewannakul, K., Mintz, Y., Frost, L.S., Ippen-Ihler, K., 1993. The Escherichia coli K-12 
F plasmid gene $\operatorname{traX}$ is required for acetylation of $\mathrm{F}$ pilin. $\mathrm{J}$. Bacteriol. 175, 1375-1383.

Motallebi-Veshareh, M., Balzer, D., Lanka, E., Jagura-Burdzy, G., Thomas, C.M., 1992. Conjugative transfer functions of broad-host-range plasmid RK2 are coregulated with vegetative replication. Mol. Microbiol. 6, 907-920.

Nagai, H., Cambronne, E.D., Kagan, J.C., Amor, J.C., Kahn, R.A., Roy, C.R., 2005. A C-terminal translocation signal required for Dot/Icm-dependent delivery of the Legionella RalF protein to host cells. Proc. Natl. Acad. Sci. USA 102, 826-831.

Nicosia, A., Perugini, M., Franzini, C., Casagli, M.C., Borri, M.G., Antoni, G., Almoni, M., Neri, P., Ratti, G., Rappuoli, R., 1986. Cloning and sequencing of the pertussis toxin genes: operon structure and gene duplication. Proc. Natl. Acad. Sci. USA 83, 4631-4635.

Novotny, C.P., Lavin, K., 1971. Some effects of temperature on the growth of F pili. J. Bacteriol. 107, 671-682.

Ogata, H., Audic, S., Renesto-Audiffren, P., Fournier, P.E., Barbe, V., Samson, D., Roux, V., Cossart, P., Weissenbach, J., Claverie, J.M., Raoult, D., 2001. Mechanisms of evolution in Rickettsia conorii and R. prowazekii. Science 293, 20932098.

Ohashi, N., Zhi, N., Lin, Q., Rikihisa, Y., 2002. Characterization and transcriptional analysis of gene clusters for a type IV secretion machinery in human granulocytic and monocytic ehrlichiosis agents. Infect. Immun. 70, 2128-2138.

Panicker, M.M., Minkley Jr., E.G., 1992. Purification and properties of the F sex factor TraD protein, an inner membrane conjugal transfer protein. J. Biol. Chem. 267, 1276112766.

Pansegrau, W., Lanka, E., 1996a. Enzymology of DNA transfer by conjugative mechanisms. Prog. Nucleic Acid Res. Mol. Biol. 54, 197-251.

Pansegrau, W., Lanka, E., 1996b. Mechanisms of initiation and termination reactions in conjugative DNA processing. Independence of tight substrate binding and catalytic activity of relaxase (TraI) of IncP $\alpha$ plasmid RP4. J. Biol. Chem. 271, 13068-13076.

Patel, S., Latterich, M., 1998. The AAA team: related ATPases with diverse functions. Trends Cell Biol. 8, 65-71.

Planet, P.J., Kachlany, S.C., DeSalle, R., Figurski, D.H., 2001. Phylogeny of genes for secretion NTPases: identification of the widespread $\operatorname{tadA}$ subfamily and development of a diagnostic key for gene classification. Proc. Natl. Acad. Sci. USA 98, 2503-2508.

3Rain, J.C., Selig, L., De Reuse, H., Battaglia, V., Reverdy, C., Simon, S., Lenzen, G., Petel, F., Wojcik, J., Schachter, V., Chemama, Y., Labigne, A., Legrain, P., 2001. The proteinprotein interaction map of Helicobacter pylori. Nature 409, 211-215.

Rambow-Larsen, A.A., Weiss, A.A., 2002. The PtlE protein of Bordetella pertussis has peptidoglycanase activity required for Ptl-mediated pertussis toxin secretion. J. Bacteriol. 184, 2863-2869.

Riede, I., Eschbach, M.L., 1986. Evidence that TraT interacts with OmpA of Escherichia coli. FEBS Lett. 205, 241-245.
Rivas, S., Bolland, S., Cabezón, E., Goñi, F.M., de la Cruz, F., 1997. TrwD, a protein encoded by the IncW plasmid R388, displays an ATP hydrolase activity essential for bacterial conjugation. J. Biol. Chem. 272, 25583-25590.

Rohde, M., Püls, J., Buhrdorf, R., Fischer, W., Haas, R., 2003. A novel sheathed surface organelle of the Helicobacter pylori cag type IV secretion system. Mol. Microbiol. 49, 219-234.

Sagulenko, E., Sagulenko, V., Chen, J., Christie, P.J., 2001a. Role of Agrobacterium VirB11 ATPase in T-pilus assembly and substrate selection. J. Bacteriol. 183, 5813-5825.

Sagulenko, V., Sagulenko, E., Jakubowski, S., Spudich, E., Christie, P.J., 2001b. VirB7 lipoprotein is exocellular and associates with the Agrobacterium tumefaciens T pilus. J. Bacteriol. 183, 3642-3651.

Salmond, G.P.C., 1994. Secretion of extracellular virulence factors by plant pathogenic bacteria. Ann. Rev. Phytopathol. $32,181-200$.

Samuels, A.L., Lanka, E., Davies, J.E., 2000. Conjugative junctions in RP4-mediated mating of Escherichia coli. J. Bacteriol. 182, 2709-2715.

Savvides, S.N., Yeo, H.J., Beck, M.R., Blaesing, F., Lurz, R., Lanka, E., Buhrdorf, R., Fischer, W., Haas, R., Waksman, G., 2003. VirB11 ATPases are dynamic hexameric assemblies: new insights into bacterial type IV secretion. EMBO J. 22, 1969-1980.

Schmidt-Eisenlohr, H., Domke, N., Angerer, C., Wanner, G., Zambryski, P.C., Baron, C., 1999a. Vir proteins stabilize VirB5 and mediate its association with the T pilus of Agrobacterium tumefaciens. J. Bacteriol. 181, 7485-7492.

Schmidt-Eisenlohr, H., Domke, N., Baron, C., 1999b. TraC of IncN plasmid pKM101 associates with membranes and extracellular high-molecular-weight structures in Escherichia coli. J. Bacteriol. 181, 5563-5571.

Schröder, G., Lanka, E., 2003. TraG-like proteins of type IV secretion systems: functional dissection of the multiple activities of TraG (RP4) and TrwB (R388). J. Bacteriol. 185, 0000 .

Schröder, G., Krause, S., Zechner, E.L., Traxler, B., Yeo, H.J., Lurz, R., Waksman, G., Lanka, E., 2002. TraG-like proteins of DNA transfer systems and of the Helicobacter pylori type IV secretion system: inner membrane gate for exported substrates? J. Bacteriol. 184, 2767-2779.

Schröder, G., Savvides, S.N., Waksman, G., Lanka, E., 2005. The type IV secretion machinery. In: Waksman, G., Caparon, M.G., Hultgren, S.J. (Eds.), Structural Biology of Bacterial Pathogenesis. ASM press, Washington, DC, pp. 000-000 (in press).

Schulein, R., Guye, P., Rhomberg, T.A., Schmid, M.C., Schröder, G., Vergunst, A.C., Carena, I., Dehio, C., 2005. A bipartite signal mediates the transfer of type IV secretion substrates of Bartonella henselae into human cells. Proc. Natl. Acad. Sci. USA 102, 856-861.

Segal, G., Feldman, M., Zusman, T., 2005. The Icm/Dot type-IV secretion systems of Legionella pneumophila and Coxiella burnetii. FEMS Microbiol. Rev. 29, 65-81.

Sexton, J.A., Vogel, J.P., 2002. Type IVB secretion by intracellular pathogens. Traffic 3, 178-185. 
Sexton, J.A., Pinkner, J.S., Roth, R., Heuser, J.E., Hultgren, S.J., Vogel, J.P., 2004. The Legionella pneumophila PilT homologue DotB exhibits ATPase activity that is critical for intracellular growth. J. Bacteriol. 186, 1658-1666.

Shamaei-Tousi, A., Cahill, R., Frankel, G., 2004. Interaction between protein subunits of the type IV secretion system of Bartonella henselae. J. Bacteriol. 186, 4796-4801.

Shirasu, K., Kado, C.I., 1993. Membrane location of the Ti plasmid VirB proteins involved in the biosynthesis of a pilin-like conjugative structure on Agrobacterium tumefaciens. FEMS Microbiol. Lett. 111, 287-294.

Shirasu, K., Koukol•'ková-Nicola, Z., Hohn, B., Kado, C.I., 1994. An inner-membrane-associated virulence protein essential for T- DNA transfer from Agrobacterium tumefaciens to plants exhibits ATPase activity and similarities to conjugative transfer genes. Mol. Microbiol. 11, 581-588.

Simone, M., McCullen, C.A., Stahl, L.E., Binns, A.N., 2001. The carboxy-terminus of VirE2 from Agrobacterium tumefaciens is required for its transport to host cells by the virB-encoded type IV transport system. Mol. Microbiol. 41, 1283-1293.

Skurray, R.A., Hancock, R.E., Reeves, P., 1974. Con ${ }^{-}$mutants: class of mutants in Escherichia coli K-12 lacking a major cell wall protein and defective in conjugation and adsorption of a bacteriophage. J. Bacteriol. 119, 726-735.

Spudich, G.M., Fernandez, D., Zhou, X.R., Christie, P.J., 1996. Intermolecular disulfide bonds stabilize VirB7 homodimers and VirB7/VirB9 heterodimers during biogenesis of the Agrobacterium tumefaciens T-complex transport apparatus. Proc. Natl. Acad. Sci. USA 93, 7512-7517.

Stein, M., Rappuoli, R., Covacci, A., 2000. Tyrosine phosphorylation of the Helicobacter pylori CagA antigen after cag driven host cell translocation. Proc. Natl. Acad. Sci. USA 97, $1263-1268$.

Story, R.M., Steitz, T.A., 1992. Structure of the recA proteinADP complex. Nature 355, 374-376.

Strauch, E., Goelz, G., Knabner, D., Konietzny, A., Lanka, E., Appel, B., 2003. A cryptic plasmid of Yersinia enterocolitica encodes a conjugative transfer system related to the regions of CloDF13 Mob and IncX Pil. Microbiology 149, 2829-2845.

Szpirer, C.Y., Faelen, M., Couturier, M., 2000. Interaction between the RP4 coupling protein TraG and the pBHR1 mobilization protein Mob. Mol. Microbiol. 37, 12831292.

Tanaka, J., Suzuki, T., Mimuro, H., Sasakawa, C., 2003. Structural definition on the surface of Helicobacter pylori type IV secretion apparatus. Cell. Microbiol. 5, 395-404.

Terradot, L., Bayliss, R., Oomen, C., Leonard, G.A., Baron, C., Waksman, G., 2005. Structures of two core subunits of the bacterial type IV secretion system, VirB8 from Brucella suis and ComB10 from Helicobacter pylori. Proc. Natl. Acad. Sci. USA $102,4596-4601$.

Terradot, L., Durnell, N., Li, M., Ory, J., Labigne, A., Legrain, P., Colland, F., Waksman, G., 2004. Biochemical characterization of protein complexes from the Helicobacter pylori protein interaction map: strategies for complex formation and evidence for novel interactions within type IV secretion systems. Mol. Cell. Proteomics 3, 809-819.
Thorstenson, Y.R., Zambryski, P.C., 1994. The essential virulence protein VirB8 localizes to the inner membrane of Agrobacterium tumefaciens. J. Bacteriol. 176, 1711-1717.

Thorstenson, Y.R., Kuldau, G.A., Zambryski, P.C., 1993. Subcellular localization of seven VirB proteins of Agrobacterium tumefaciens: implications for the formation of a T-DNA transport structure. J. Bacteriol. 175, 5233-5241.

Trieu-Cuot, P., Carlier, C., Martin, P., Courvalin, P., 1987. Plasmid transfer by conjugation from Escherichia coli to Gram-positive bacteria. FEMS Microbiol. Lett. 48, 289294.

van Mansfeld, A.D., van Teeffelen, H.A., Baas, P.D., Jansz, H.S., 1986. Two juxtaposed tyrosyl-OH groups participate in $\phi$ X174 gene A protein catalysed cleavage and ligation of DNA. Nucleic Acids Res. 14, 4229-4238.

Vergunst, A.C., van Lier, M.C., den Dulk-Ras, A., Hooykaas, P.J.J., 2003. Recognition of the Agrobacterium tumefaciens VirE2 translocation signal by the VirB/D4 transport system does not require VirE1. Plant Physiol. 133, 978-988.

Vergunst, A.C., Schrammeijer, B., Dulk-Ras, A., de Vlaam, C.M., Regensburg-Tuink, T.J., Hooykaas, P.J.J., 2000. VirB/ D4-dependent protein translocation from Agrobacterium into plant cells. Science 290, 979-982.

Vergunst, A.C., van Lier, M.C., den Dulk-Ras, A., Stuve, T.A., Ouwehand, A., Hooykaas, P.J.J., 2005. Positive charge is an important feature of the C-terminal transport signal of the VirB/D4-translocated proteins of Agrobacterium. Proc. Natl. Acad. Sci. USA 102, 832-837.

Walker, J.E., Saraste, M., Runswick, M.J., Gay, N.J., 1982. Distantly related sequences in the $\alpha$ - and $\beta$-subunits of ATP synthase, myosin, kinases, and other ATP-requiring enzymes and a common nucleotide binding fold. EMBO J. 1, 945-951.

Ward, D.V., Draper, O., Zupan, J.R., Zambryski, P.C., 2002. Peptide linkage mapping of the Agrobacterium tumefaciens vir-encoded type IV secretion system reveals protein subassemblies. Proc. Natl. Acad. Sci. USA 99, 11493-11500.

Waters, V.L., 1999. Conjugative transfer in the dissemination of beta-lactam and aminoglycoside resistance. Front. Biosci. 4 , D433-D456.

Waters, V.L., 2001. Conjugation between bacterial and mammalian cells. Nat. Genet. 29, 375-376.

Wegrzyn, G., 2005. What does "plasmid biology" currently mean? Summary of the Plasmid Biology 2004 Meeting. Plasmid 53, 14-22.

Weiss, A.A., Johnson, F.D., Burns, D.L., 1993. Molecular characterization of an operon required for pertussis toxin secretion. Proc. Natl. Acad. Sci. USA 90, 2970-2974.

Whitchurch, C.B., Hobbs, M., Livingston, S.P., Krishnapillai, V., Mattick, J.S., 1991. Characterisation of a Pseudomonas aeruginosa twitching motility gene and evidence for a specialised protein export system widespread in eubacteria. Gene $101,33-44$.

Willetts, N., 1981. Sites and systems for conjugal DNA transfer in bacteria. In: Levy, S.B., Clowes, R.C., Koenig, E.L. (Eds.), Molecular Biology, Pathogenicity and Ecology of Bacterial Plasmids. Plenum Press, New York, pp. 207-215. 
Winans, S.C., Walker, G.C., 1985. Conjugal transfer system of the IncN plasmid pKM101. J. Bacteriol. 161, 402-410.

Ye, Y., Meyer, H.H., Rapoport, T.A., 2001. The AAA ATPase Cdc48/p97 and its partners transport proteins from the ER into the cytosol. Nature 414, 652-656.

Yeo, H.J., Savvides, S.N., Herr, A.B., Lanka, E., Waksman, G., 2000. Crystal structure of the hexameric traffic ATPase of the Helicobacter pylori type IV secretion system. Mol. Cell 6, 1461-1472.

Yeo, H.J., Yuan, Q., Beck, M.R., Baron, C., Waksman, G., 2003. Structural and functional characterization of the VirB5 protein from the type IV secretion system encoded by the conju- gative plasmid pKM101. Proc. Natl. Acad. Sci. USA 100, 15947-15952.

Zamboni, D.S., McGrath, S., Rabinovitch, M., Roy, C.R., 2003. Coxiella burnetii express type IV secretion system proteins that function similarly to components of the Legionella pneumophila Dot/Icm system. Mol. Microbiol. 49, 965-976.

Zylicz, M., LeBowitz, J.H., McMacken, R., Georgopoulos, C., 1983. The dnaK protein of Escherichia coli possesses an ATPase and autophosphorylating activity and is essential in an in vitro DNA replication system. Proc. Natl. Acad. Sci. USA $80,6431-6435$. 